\title{
1 Immunogenic profile of SARS-CoV-2 spike in 2 individuals recovered from COVID-19 \\ 3
}

4 Jennifer A Juno ${ }^{1 *}$, Hyon-Xhi Tan ${ }^{1 *}$, Wen Shi Lee ${ }^{1}$, Arnold Reynaldi², Hannah G 5 Kelly ${ }^{1,3}$, Kathleen Wragg ${ }^{1}$, Robyn Esterbauer ${ }^{1,3}$, Helen E Kent ${ }^{1,4}$, C Jane Batten ${ }^{1}$,

6 Francesca L Mordant ${ }^{1}$, Nicholas A Gherardin ${ }^{1,5}$, Phillip Pymm ${ }^{6,7}$, Melanie H 7 Dietrich $^{6,7}$, Nichollas E Scott ${ }^{1}$, Wai-Hong Tham ${ }^{6}$, Dale I Godfrey ${ }^{1,5}$, Kanta 8 Subbarao $^{1,8}$, Miles P Davenport ${ }^{2}$, Stephen J Kent ${ }^{1,3,4} \uparrow^{*}$, Adam K Wheatley ${ }^{1,3} \dagger^{*}$

$9 *$ Equally contributed

${ }^{1}$ Department of Microbiology and Immunology, University of Melbourne, at The Peter Doherty Institute for Infection and Immunity, Melbourne, Victoria 3000, Australia

${ }^{2}$ Kirby Institute, University of New South Wales, Kensington, NSW 2052, Australia

${ }^{3}$ Australian Research Council Centre for Excellence in Convergent Bio-Nano Science and Technology, University of Melbourne, Melbourne, Victoria 3010, Australia

${ }^{4}$ Melbourne Sexual Health Centre and Department of Infectious Diseases, Alfred Hospital and Central Clinical School, Monash University, Melbourne, Victoria 3004, Australia

${ }^{5}$ Australian Research Council Centre of Excellence in Advanced Molecular Imaging, University of Melbourne, Melbourne, Victoria 3010, Australia

${ }^{6}$ The Walter and Eliza Hall Institute of Medical Research, Parkville, Victoria 3052, Australia.

${ }^{7}$ Department of Medical Biology, The University of Melbourne, Melbourne, Victoria 3010, Australia.

${ }^{8}$ WHO Collaborating Centre for Reference and Research on Influenza, The Peter Doherty Institute for Infection and Immunity, 792 Elizabeth Street, Melbourne, VIC 3000, Australia

$\uparrow$ Corresponding authors. Address to Stephen Kent, Department of Microbiology and Immunology, Doherty Institute, 792 Elizabeth St, Melbourne, Victoria, Australia 3000. Phone +61 38344 9939. Email: skent@unimelb.edu.au. Or Adam Wheatley, Department of Microbiology and Immunology, Doherty Institute, 792 Elizabeth St, Melbourne, Victoria, Australia 3000. Email: awheatley@unimelb.edu.au

NOTE: This preprint reports new research that has not been certified by peer review and should not be used to guide clinical practice. 
medRxiv preprint doi: https://doi.org/10.1101/2020.05.17.20104869; this version posted May 21, 2020. The copyright holder for this preprint

(which was not certified by peer review) is the author/funder, who has granted medRxiv a license to display the preprint in perpetuity.

\section{Abstract}

34 The rapid global spread of SARS-CoV-2 and resultant mortality and social disruption

35 have highlighted the need to better understand coronavirus immunity to expedite 36 vaccine development efforts. Multiple candidate vaccines, designed to elicit 37 protective neutralising antibodies targeting the viral spike glycoprotein, are rapidly 38 advancing to clinical trial. However, the immunogenic properties of the spike protein 39 in humans are unresolved. To address this, we undertook an in-depth characterisation 40 of humoral and cellular immunity against SARS-CoV-2 spike in humans following 41 mild to moderate SARS-CoV-2 infection. We find serological antibody responses 42 against spike are routinely elicited by infection and correlate with plasma neutralising activity and capacity to block ACE2/RBD interaction. Expanded populations of spikespecific memory B cells and circulating T follicular helper cells (cTFH) were detected within convalescent donors, while responses to the receptor binding domain (RBD) constitute a minor fraction. Using regression analysis, we find high plasma neutralisation activity was associated with increased spike-specific antibody, but notably also with the relative distribution of spike-specific cTFH subsets. Thus both qualitative and quantitative features of $\mathrm{B}$ and $\mathrm{T}$ cell immunity to spike constitute informative biomarkers of the protective potential of novel SARS-CoV-2 vaccines. 
medRxiv preprint doi: https://doi.org/10.1101/2020.05.17.20104869; this version posted May 21, 2020. The copyright holder for this preprint

(which was not certified by peer review) is the author/funder, who has granted medRxiv a license to display the preprint in perpetuity.

\section{Introduction}

54 The rapid global spread of SARS-CoV-2 has highlighted the intrinsic vulnerability of

55 humans to emerging zoonotic infections and spurred frantic efforts to expedite 56 vaccine and antiviral drug development, manufacture and deployment. In contrast to 57 historical pandemics, such as the 1918 "Spanish" H1N1 influenza, modern 58 recombinant technology enables a rapid scientific response, with multiple vaccines 59 under development, almost exclusively aimed at eliciting antibodies to the viral 60 "spike" protein.

61

62

The spike (S) protein of beta-coronaviruses is expressed as a single protein, with proteolytic cleavage yielding S1 and S2 subunits ${ }^{1}$. S localises on the virion surface and mediates both recognition of cellular receptors and membrane fusion. In the case of SARS-CoV-2, a receptor binding domain (RBD) within S1 directly interacts with high affinity with the peptidase domain of angiotensin-converting enzyme 2 (ACE2) ${ }^{2-4}$. The S2 subunit of S mediates membrane fusion. The S/ACE2 interaction mediates viral entry and provides an attractive target for vaccine-elicited humoral immunity ${ }^{5}$, with antibodies potentially capable of either (i) directly blocking binding of ACE2 by $\mathrm{S}$, (ii) blocking conformational changes in $\mathrm{S}$ critical for membrane fusion, (iii) eliminating infected cells through antibody effector mechanisms such as antibodydependent cellular cytotoxicity (ADCC), or (iv) driving accelerated clearance of free virus.

The dominant targets for human antibody against the SARS-CoV-2 S are unclear. Some human mAbs originally characterised against SARS-CoV S cross-react with SARS-Cov-2. For example CR3022 which binds a cryptic epitope on the RBD ${ }^{6,7}$, while S309, derived from the memory B cells of a SARS-CoV recovered subject, 
medRxiv preprint doi: https://doi.org/10.1101/2020.05.17.20104869; this version posted May 21, 2020. The copyright holder for this preprint

(which was not certified by peer review) is the author/funder, who has granted medRxiv a license to display the preprint in perpetuity.

blocks ACE2 engagement by SARS-CoV-2 $\mathrm{S}^{8}$. A recent report of monoclonal antibodies recovered from SARS-CoV-2 convalescent donors revealed multiple nonoverlapping epitopes on the RBD, with different capacities for mediating neutralisation ${ }^{9}$. Few neutralising epitopes localised outside the RBD have been characterised to date, with preliminary reports of neutralising epitopes within the Nterminal domain of $\mathrm{S}^{10}$. Nevertheless, studies of other zoonotic human coronaviruses MERS-CoV and SARS-CoV have identified epitopes in both the N-terminal domain of S1 or within S2 can neutralise virus infection by blocking critical viral functions such as membrane fusion ${ }^{11-14}$.

Given the capacity to prevent viral infection, eliciting antibodies to $\mathrm{S}$ by immunisation is of intense interest and multiple human vaccines targeting $\mathrm{S}$ are in various stages of clinical development (reviewed in ${ }^{15,16}$ ). However, although an inactivated SARS-CoV-2 vaccine showed promise in animal models ${ }^{17}$, the immunogenic properties of SARS-CoV, MERS-CoV or SARS-CoV-2 S-based immunogens in humans are poorly resolved. Here we undertook an in-depth characterisation of humoral and cellular immunity against spike in humans who recovered from mild to moderate SARS-CoV-2 infection. We find antibody responses to both S and the RBD are consistently elicited following SARS-CoV-2 infection, the magnitude of which correlates with both plasma neutralising activity and inhibition of RBD/ACE2 binding. S-specific B cells comprise a significant proportion of the circulating memory B cell pool following infection, with RBD-specific B cells constituting a minor subpopulation in most subjects. Assessment of the circulating T follicular helper (cTFH) population reveals that S-specific cTFH cells are also readily detected in convalescent subjects, while $\mathrm{T}$ cell responses toward the $\mathrm{RBD}$ are 
medRxiv preprint doi: https://doi.org/10.1101/2020.05.17.20104869; this version posted May 21, 2020. The copyright holder for this preprint

(which was not certified by peer review) is the author/funder, who has granted medRxiv a license to display the preprint in perpetuity.

All rights reserved. No reuse allowed without permission.

104 significantly lower in frequency. Finally, we find the development of comparatively

105 high plasma neutralisation activity is associated not only with the magnitude of anti-S

106 immune responses, but also with the phenotype of circulating TFH populations,

107 suggesting these features may serve as attractive biomarkers for candidate S-based

108 vaccines entering the clinic.

\section{Results}

\section{Serological responses to spike antigens following SARS-CoV-2 infection}

111 We recruited a cross-sectional cohort $(\mathrm{N}=41)$ of Australian adults recovered from

112 mild-moderate SARS-CoV-2 infection and isolated plasma and PBMC samples at a

113 median of 32 (IQR: 28-35) days post-positive PCR test. The cohort had a median age

114 of 59 (IQR: 54-65) and was 43\% female (17 of 41). Subjects reported mild to

115 moderate upper and lower respiratory tract symptoms with only $5(12 \%)$ requiring

116 hospitalisation, and none requiring mechanical ventilation (Table S1). A control

117 cohort of 27 healthy adults was recruited prior to widespread infection in Australia

118 (Table S2). As we had an interest in the degree to which baseline cross-reactive

119 coronavirus immunity affected SARS-CoV-2 responses, we pre-screened the 27

120 uninfected subjects for serological reactivity against the beta coronavirus $\mathrm{HCoV}$ -

121 HKU1 (HKU1) (Figure S1), selecting individuals with the 5 highest and 5 lowest

122 plasma titres as controls for the study.

124 Serological profiles are presented stratified across the cohort based on neutralisation

125 activity for each subject. Antibodies binding the SARS-CoV-2 spike (Figure 1A) or

126 the RBD (Figure 1B) were consistently observed in all 41 infected individuals by

127 ELISA, with minimal reactivity in the controls. Titres of S- and RBD-specific

128 antibody were highly correlated (Figure S2). Consistent with previous reports ${ }^{18}$, low- 
medRxiv preprint doi: https://doi.org/10.1101/2020.05.17.20104869; this version posted May 21, 2020. The copyright holder for this preprint

(which was not certified by peer review) is the author/funder, who has granted medRxiv a license to display the preprint in perpetuity.

129 level antibody responses cross-recognising the SARS-CoV RBD were observed in

130 most of our SARS-CoV-2 infected cohort (Figure 1C). Antibody responses to the

131 human coronavirus strain HKU were prevalent at moderate to high levels across the

132 cohort, in line with previous reports of widespread seropositivity to S proteins of

133 human coronaviruses in adults ${ }^{19,20}$ (Figure 1D). The capacity of immune plasma to

134 block interaction between recombinant ACE2 and RBD was assessed by ELISA, with

135 modest levels of inhibition detected in most subjects, and selected subjects exhibiting

136 potent inhibitory activity (Figure 1E). Virus neutralising activity in the plasma was

137 similarly assessed using a microneutralisation assay with live SARS-CoV-2 infection

138 of Vero cells as previously described for SARS-CoV and MERS-CoV ${ }^{21,22}$.

139 Neutralising antibody titres ranged from 40 to 508 (IQR:113-254) (Figure 1F). In

140 summary, antibody responses against both S and the RBD are consistently elicited in

141 SARS-CoV-2 infected individuals, the endpoints titres of which correlate significantly

142 with neutralising activity ( $\mathrm{r}=0.55$ and $\mathrm{r}=0.61$ respectively) and ACE2 binding

143 inhibition $(\mathrm{r}=0.72$ and $\mathrm{r}=0.72$ respectively) in the plasma (Figure $\mathrm{S} 2)$.

\section{B cell responses to S antigens following SARS-CoV-2 infection}

146 We next examined the frequency and specificity of class-switched B cells in

147 convalescent subjects using SARS-CoV-2 spike or RBD proteins as flow cytometric

148 probes. Clear antigen-specific populations of $\mathrm{CD} 19^{+} \mathrm{IgD}^{-} \mathrm{B}$ cells (gating in Figure $\mathrm{S} 3$ )

149 binding spike, spike and RBD or RBD alone could be resolved in our cohort of

150 recovered from SARS-CoV-2 subjects, with minimal background staining in

151 uninfected controls (Figure 2A; Figure S4). Frequencies of spike ${ }^{+} \mathrm{RBD}^{-}, \mathrm{spike}^{+} \mathrm{RBD}^{+}$

152 and spike- $\mathrm{RBD}^{+} \mathrm{B}$ cells as a proportion of the $\mathrm{CD} 19^{+} \mathrm{IgD}^{-}$population were a median

$1530.38 \%$ (IQR 0.24-0.52), 0.047\% (IQR 0.023-0.084) and 0.033\% (IQR 0.015-0.045), 
medRxiv preprint doi: https://doi.org/10.1101/2020.05.17.20104869; this version posted May 21, 2020. The copyright holder for this preprint

(which was not certified by peer review) is the author/funder, who has granted medRxiv a license to display the preprint in perpetuity.

154 respectively (Figure 2B). The very low frequencies of spike- $\mathrm{RBD}^{+} \mathrm{B}$ cells likely

155 constitute a mix of background staining and B cells that recognise RBD epitopes

156 occluded in recombinant $\mathrm{S}$ or intact virus. Immunoglobulin isotypes were determined

157 for spike ${ }^{+} \mathrm{RD}^{-}$and spike ${ }^{+} \mathrm{RBD}^{+}$populations using $\operatorname{IgM}$ and $\operatorname{IgG}$ surface staining,

158 with IgM-IgG- class-switched B cells previously established to be almost exclusively

$159 \operatorname{IgA}^{+23}$. In our cohort sampled a median of 36 days after symptom onset, the majority

160 of spike ${ }^{+} \mathrm{RBD}^{-}$class-switched B cells were $\mathrm{IgG}^{+}$(median 57.5\%; IQR 46.8-64.8), with

161 smaller proportions displaying $\operatorname{IgM}+\left(20.9 \%\right.$; IQR 17.4-29.1) and $\operatorname{IgA}^{+}\left(\operatorname{IgM}^{-} \operatorname{IgG}{ }^{-}\right)$

162 (17.4\%; IQR 13.2-25.9) (Figure 2C). Isotype distribution of spike ${ }^{+} \mathrm{RBD}^{+} \mathrm{B}$ cells was

163 more variable due to low event counts, with median frequencies of $45.5 \%$ (IQR 27.8-

164 70.7) $\operatorname{IgG}, 13.6 \%$ (IQR 0-30.3) IgM and 20.0\% IgA (IQR 4.73-41.9). The activation

165 phenotype of antigen-specific B cells was assessed using CD21 and CD27 surface

166 staining ${ }^{24}$ (Figure S5). Most spike $^{+} \mathrm{RBD}^{-}$(median 58.5\%; IQR 52.2-66.6) or

167 spike ${ }^{+} \mathrm{RBD}^{+}(68.7 \%$; IQR 54.4-80) class-switched B cells displayed a resting memory

168 phenotype $\left(\mathrm{CD} 21^{+} \mathrm{CD} 27^{+}\right)$, also consistent with the median duration of infection.

169 However, a significant proportion of activated memory B cells $\left(\mathrm{CD} 21^{-} \mathrm{CD} 27^{+}\right)$was

170 still evident for both spike ${ }^{+} \mathrm{RBD}^{-}(18.9 \%$; IQR $13.2-25.7)$ or spike $^{+} \mathrm{RBD}^{+} \mathrm{B}$ cell

171 populations (13.2\%; IQR 5.88-20), with only low proportions of $\mathrm{CD} 21^{-\mathrm{CD}} 27^{-}$and

$172 \mathrm{CD}^{2} 1^{+} \mathrm{CD} 27^{-}$phenotypes observed. Overall, SARS-CoV-2 infection efficiently elicits

173 both S- and RBD-specific B cells in most subjects after recovery, which constitute a

174 significant proportion of the memory B cell pool, which are mostly $\operatorname{IgG}^{+}$and of a

175 resting memory phenotype.

177 The RBD of SARS-CoV and SARS-CoV-2 share significant homology, but with

178 marked diversity within the ACE2 binding motif despite shared recognition of this 
medRxiv preprint doi: https://doi.org/10.1101/2020.05.17.20104869; this version posted May 21, 2020. The copyright holder for this preprint

(which was not certified by peer review) is the author/funder, who has granted medRxiv a license to display the preprint in perpetuity. All rights reserved. No reuse allowed without permission.

179 cellular receptor ${ }^{2,25}$. We examined whether differential staining with SARS-CoV and

180 SARS-CoV-2 probes would allow more precise identification of B cells recognising

181 the unique ACE2 binding site of SARS-CoV-2, to understand why some individuals

182 had notable RBD-specific antibody titres but with limited neutralisation activity or

$183 \mathrm{RBD} / \mathrm{ACE} 2$ binding inhibition. PBMCs from a subset of COVID+ subjects $(\mathrm{N}=15)$

184 were stained with SARS-CoV-2 spike, SARS-CoV-2 RBD and SARS-CoV RBD

185 probes as before (Figure 2D). Both SARS-CoV-2 RBD-specific and SARS-

$186 \mathrm{CoV} / \mathrm{SARS}-\mathrm{CoV}-2$ cross-reactive $\mathrm{IgG}+\mathrm{B}$ cells could be resolved in most subjects

187 (Figure S6), with cells binding only SARS-CoV-2 RBD making up the major fraction

188 of the spike ${ }^{+} \mathrm{RBD}^{+}$response (Figure 2E). However, while increased proportions of

189 SARS-CoV-2 RBD-specific B cells within the spike ${ }^{+}$response does broadly track

190 with plasma blockade of RBD/ACE2 binding (Figure 2F; r=0.46), we find no

191 correlation with neutralisation activity (Figure 2G:r=0.05).

192 CD4 T cell responses to $S$ antigens following SARS-CoV-2 infection

193 TFH provide critical cognate help to antigen-specific B cells to initiate and maintain

194 humoral immune responses ${ }^{26}$. Circulating TFH cells $\left(\mathrm{cTFH} ; \mathrm{CD}^{+} \mathrm{CD}^{+} \mathrm{CD}^{2} 5 \mathrm{RA}^{-}\right.$

$195 \mathrm{CXCR}^{+}$, gating in Figure S7) in the blood provide a surrogate indication of TFH

196 activity in lymphoid tissues ${ }^{27,28}$. Total unstimulated cTFH frequencies were similar

197 across SARS-CoV-2 convalescent and uninfected donors (Figure S8). Antigen

198 specificity of the cTFH population was determined using an activation induced

199 marker (AIM) assay ${ }^{29}$ in response to stimulation with SARS-CoV-2 spike or RBD

200 proteins (Figure 3A). Overall, recovered subjects exhibited robust cTFH responses to

201 the SARS-CoV-2 spike protein, with a median of $0.92 \%$ spike-specific cTFH cells

202 (IQR 0.42 - 1.52; Figure 3B). In contrast to the full spike, RBD-specific cTFH

203 responses were significantly lower $(\mathrm{p}<0.0001)$, with a median of only $0.12 \%$ of cTFH 
medRxiv preprint doi: https://doi.org/10.1101/2020.05.17.20104869; this version posted May 21, 2020. The copyright holder for this preprint

(which was not certified by peer review) is the author/funder, who has granted medRxiv a license to display the preprint in perpetuity.

204 cells exhibiting RBD specificity (IQR 0.04 - 0.38). Consistent with the high

205 frequency of HKU1 seropositivity among the convalescent cohort (Figure 1D), cTFH 206 responses to HKU1 spike were detected among $97.5 \%$ of donors (median $0.52 \%$ of 207 cTFH cells, IQR 0.32 - 0.99). The frequency of HKU1-specific cTFH was generally 208 higher among the convalescent cohort than the uninfected controls (Figure 3B), 209 suggesting a boosting of cross-reactive $\mathrm{T}$ cell responses following SARS-CoV-2 210 infection.

212 cTFH populations have classically been divided on the basis of surface expression of 213 chemokine receptors CCR6 and CXCR3 ${ }^{28,30,31}$. However the functional capacities 214 and relevance of putative cTFH1 (CCR6-CXCR3 $\left.{ }^{+}\right)$, cTFH2 (CCR6-CXCR3 ${ }^{-}$) and 215 TH17-like $\left(\mathrm{CCR}^{+} \mathrm{CXCR}^{-}\right)$cTFH subsets are still unclear and may be pathogen216 dependent or vary with anatomical location $27,28,31$. In contrast to the total 217 unstimulated cTFH population, SARS-CoV-2 spike and HKU-specific cTFH were 218 enriched for $\mathrm{CCR}^{+} \mathrm{CXCR}^{-}$cells (median 52.6\% of SARS-CoV-2 spike-specific, $21962.9 \%$ of HKU1 spike-specific or $21.1 \%$ of bulk cTFH, $\mathrm{p}<0.0001$, Figure $3 \mathrm{C} / 3 \mathrm{D}$ ). 220 Comparison to SEB-stimulated cells from a subset of donors confirmed that in vitro 221 TCR stimulation does not preferentially activate or upregulate expression of CCR6 222 among the cTFH population (Figure 3D).

224 Analysis of spike-specific non-cTFH CD4 memory $\left(\mathrm{CD}^{+} \mathrm{CD}^{+}{ }^{+} \mathrm{CD} 45 \mathrm{RA}^{-} \mathrm{CXCR} 5^{-}\right)$ 225 cells revealed similar patterns of antigen reactivity to the cTFH compartment; namely, 226 strong recognition of SARS-CoV-2 and HKU1 spike proteins (median $0.53 \%$ and $2270.54 \%$ of CD4 memory cells, respectively) and lower frequencies of RBD-specific T 228 cells (median $0.24 \%$ of CD4 memory cells) (Figure S8). 
medRxiv preprint doi: https://doi.org/10.1101/2020.05.17.20104869; this version posted May 21, 2020. The copyright holder for this preprint

(which was not certified by peer review) is the author/funder, who has granted medRxiv a license to display the preprint in perpetuity.

\section{Predictors of plasma neutralisation activity}

230 The development of serological neutralisation activity will be a critical endpoint for

231 upcoming SARS-CoV-2 vaccine trials. A co-correlation matrix of subject 232 characteristics and immunological parameters was generated (Figure 4A). This 233 analysis highlighted broad co-correlation of many immune parameters related to $\mathrm{S}$

234 immunogenicity, namely antibody titres and the circulating frequencies of S-specific

$235 \mathrm{~B}$ and $\mathrm{T}$ cell populations. Principal component analysis (PCA) on immunological 236 variables revealed clustering of the cohort into subjects with stronger and weaker 237 plasma neutralisation activity (Figure 4B). Using a multiple regression approach, we 238 identified titres of S-specific antibody and the proportion of S-specific cTFH with a 239 TH17-like phenotype $\left(\mathrm{CCR}^{+} \mathrm{CXCR}^{-}\right)$as the two most significant predictive factors 240 related to neutralisation activity (Figure 4C).

\section{Discussion}

242 Efficient elicitation of potent antibodies capable of neutralising viral entry is likely to

243 be a critical feature of effective vaccines against SARS-CoV-2. In the current study, 244 we observed that neutralisation activity in the plasma of convalescent subjects ranged 245 from potent to negligible, despite near universal detection of antibodies binding $\mathrm{S}$ 246 and/or RBD, suggesting that qualitative aspects of the humoral immune response may 247 be a critical consideration for vaccine development. Direct assessment of key 248 immunological events within the respiratory tract and draining lymphoid tissues is 249 challenging in humans, however assessing B and $\mathrm{T}$ cell immunity in more readily 250 sampled blood can be informative.

252 Spike-specific class-switched B cells were expanded in nearly all infected subjects, 253 with a predominantly $\mathrm{IgG}^{+}$and resting memory phenotype consistent with the 254 sampling time several weeks after the resolution of infection. B cells binding the 
medRxiv preprint doi: https://doi.org/10.1101/2020.05.17.20104869; this version posted May 21, 2020. The copyright holder for this preprint

(which was not certified by peer review) is the author/funder, who has granted medRxiv a license to display the preprint in perpetuity.

All rights reserved. No reuse allowed without permission.

255 RBD, which contains the ACE2 interaction site, were markedly less frequent than S-

256 specific B cells, and not detected at all in many subjects. Combinatorial B cell

257 staining with both SARS-CoV and SARS-CoV-2 probes enabled focused assessment

258 of the uniquely variant epitope on the SARS-CoV-2 RBD that facilitates high affinity

259 recognition of ACE2. A minority of SARS-CoV-2 RBD-specific B cells also

260 recognise the SARS-CoV RBD, a finding consistent with the relative infrequency of

261 SARS-CoV or MERS-CoV cross-reactive antibodies recovered from convalescent

262 patients to date ${ }^{9,32}$. We find the frequency of $\operatorname{IgD}^{-} \operatorname{IgG}^{+} \mathrm{B}$ cells that bound $\mathrm{S}$ and

263 SARS-CoV-2 RBD, but not cells binding SARS-CoV RBD, tracked with serological

$264 \mathrm{RBD} / \mathrm{ACE} 2$ binding inhibition but not with overall neutralising activity. Overall, our

265 data suggest that in some subjects, precise antibody recognition and blockade of the

266 RBD ACE2-binding site is the principal pathway to generating neutralising antibody.

267 However, the disconnect seen in many subjects between plasma neutralising titres and

268 RBD-specific antibody, B and T cell responses, strongly suggests sufficient non-RBD

269 epitope targets exist to constitute an alternative pathway to comparable virus

270 neutralisation outcomes.

271

272 TFH cells provide critical help to antigen-specific B cells in lymph nodes through

273 contact-dependent (ICOS, CD154) and independent (IL-21) mechanisms ${ }^{26}$. cTFH

274 (CD45RA-CXCR5 ${ }^{+}$CD4 $\mathrm{T}$ cells) in the circulation have been suggested to serve as a

275 surrogate measure of TFH activity ${ }^{28}$. We found the frequency of SARS-CoV2 S-

276 specific cTFH elicited following infection correlated with both S-specific antibody

277 responses and S-specific B cell frequencies. In contrast, only limited cTFH responses

278 to SARS-CoV-2 RBD were observed, which may reflect limited CD4 T cell epitopes

279 given the small size of RBD. This has implications for RBD-based vaccine strategies, 
medRxiv preprint doi: https://doi.org/10.1101/2020.05.17.20104869; this version posted May 21, 2020. The copyright holder for this preprint

(which was not certified by peer review) is the author/funder, who has granted medRxiv a license to display the preprint in perpetuity.

All rights reserved. No reuse allowed without permission.

280 with inefficient recruitment of $\mathrm{T}$ cell help potentially limiting effective humoral

281 responses, as previously observed with the stem domain of influenza hemagglutinin $282 \quad 33$

284 Antigen-specific cTFH can be phenotypically characterised by surface expression of 285 CXCR3 and CCR6. Studies suggest that CCR6 $^{+}$cTFH cells produce more IL-21, 286 provide superior help to naïve B cells and more transcriptionally resemble GC TFH ${ }^{27}$, 287 while $\mathrm{CXCR}^{+}{ }^{\text {cTFH }}$ can preferentially provide help to memory B cells ${ }^{28,31}$. We find 288 SARS-CoV-2 S-specific cTFH exhibit a clear phenotypic bias toward a $289 \mathrm{CCR}^{+} \mathrm{CXCR}^{-}$phenotype (cTFH17), consistent with responses to other neo-antigens 290 such as Ebola glycoprotein vaccines ${ }^{34}$. However despite this predominance, the 291 relative proportion of S-specific cTFH17 (CCR6 $\left.{ }^{+} \mathrm{CXCR}^{-}\right)$was negatively correlated 292 with virus neutralisation activity. In contrast, increased frequencies of both cTFH1 293 (CCR6 $\left.^{-} \mathrm{CXCR}^{+}\right)$and ${ }^{-} \mathrm{TFH} 2\left(\mathrm{CCR}^{-}{ }^{-} \mathrm{CXCR}^{-}\right)$were observed in subjects with the 294 highest plasma neutralising activity. Expansion of cTFH1 is well characterized 295 following seasonal influenza immunisation, where peak frequencies in the blood 296 correlate with both plasmablast expansion and subsequent serum neutralising 297 antibody titres $23,30,35$. Similarly, bias toward CXCR3 ${ }^{+}$phenotypes is reported for 298 antigen-specific cTFH in many chronic infections ${ }^{36,37}$. The functional significance of $299 \mathrm{CXCR}^{+}$cTFH during SARS-CoV-2 infection is currently unclear, however may 300 reflect differences in lymph node TFH activity or egress from the GC.

302 The impact of widespread pre-existing immunity to human coronaviruses (229E, 303 NL63, HKU1, OC43) upon the responses to SARS-CoV-2 infection is an open 304 question. Here we found serum antibody against HKU1 was widely prevalent, 
medRxiv preprint doi: https://doi.org/10.1101/2020.05.17.20104869; this version posted May 21, 2020. The copyright holder for this preprint

(which was not certified by peer review) is the author/funder, who has granted medRxiv a license to display the preprint in perpetuity.

\section{Ethics Statement}

328 reactivity.

consistent with the high seroprevalence rates in adults reported previously 19,20 . However, we see no evidence of HKU-specific immunity modulating binding or neutralising titres against SARS-CoV-2 antigens. Our data suggest CD4 T cell responses to HKU1 may be boosted following SARS-CoV-2 infection, possibly via recognition of conserved epitopes within the S2 domain ${ }^{38}$. The predominantly CCR $6^{+}$ phenotype of SARS-CoV-2 and HKU-1-specific cTFH may reflect a coronavirusspecific TFH response, but further epitope mapping is required to deconvolute the contribution of HKU1 memory responses or recently boosted SARS-CoV-2 cross-

There is understandably considerable scientific interest in predicting the biogenesis of protective immunity against SARS-CoV-2, of which neutralising antibodies against $\mathrm{S}$ are likely to be consequential. Although the current study is limited by cohort size, we find that concomitant factors demarking robust humoral immunity, namely increased S-specific class-switched B cells, circulating TFH and antibody, all correlate with increased virus neutralisation activity. Interestingly, we find the surface phenotype of circulating TFH populations most clearly differentiated subjects with potent neutralising responses. We propose $\mathrm{B}$ cell and cTFH frequencies and phenotypes constitute informative biomarkers of immune function for assessment of upcoming clinical trials of novel vaccines targeting $\mathrm{S}$.

\section{Materials and Methods}

The study protocols were approved by the University of Melbourne Human Research

Ethics Committee (\#2056689) and all associated procedures were carried out in 
medRxiv preprint doi: https://doi.org/10.1101/2020.05.17.20104869; this version posted May 21, 2020. The copyright holder for this preprint

(which was not certified by peer review) is the author/funder, who has granted medRxiv a license to display the preprint in perpetuity.

All rights reserved. No reuse allowed without permission.

accordance with the approved guidelines. All participants provided written informed consent in accordance with the Declaration of Helsinki.

\section{Subject recruitment and sample collection}

Subjects who had recovered from COVID19 and healthy controls were recruited through contacts with the investigators and invited to provide a blood sample. Subject characteristics of SARS-CoV-2 convalescent subjects are collated in Table S1 and the healthy controls in Table S2. For all participants, whole blood was collected with sodium heparin anticoagulant. Plasma was collected and stored at $-80^{\circ} \mathrm{C}$, and PBMCs were isolated via Ficoll Paque separation, cryopreserved in $10 \%$ DMSO/FCS and stored in liquid nitrogen.

\section{Expression of coronavirus proteins and hACE2}

A set of proteins was generated for serological and flow cytometric assays. The ectodomain of SARS-CoV-2 (isolate WHU1;residues 1 - 1208) or HCoV-HKU1 S protein (isolate N5;residues 1 - 1290) were synthesised with furin cleavage site removed and P986/987 stabilisation mutations ${ }^{39}$, a C-terminal $\mathrm{T} 4$ trimerisation domain, Avitag and His-tag, expressed in Expi293 cells and purified by Ni-NTA affinity and size-exclusion chromatography using a Superose 6 16/70 column (GE Healthcare) (Figure S9). SARS-CoV S was biotinylated using Bir-A (Avidity). The SARS-CoV-2 RBD ${ }^{40}$ with a C-terminal His-tag (residues 319-541; kindly provided by Florian Krammer) was similarly expressed and purified. SARS-CoV RBD (residues N321-P513) with a C-terminal Avitag and His-tag, was expressed in Expi293 cells and purified by Ni-NTA, biotinylated using Bir-A (Avidity) and purified by izeexclusion chromatography using a S-75 Superdex (GE Healthcare). The human (residues 19-613) and mouse (residues 19-615) ACE2 ectodomain with C-terminal 
medRxiv preprint doi: https://doi.org/10.1101/2020.05.17.20104869; this version posted May 21, 2020. The copyright holder for this preprint

(which was not certified by peer review) is the author/funder, who has granted medRxiv a license to display the preprint in perpetuity.

356 His-tag (kindly provided by Merlin Thomas) were expressed in Expi293 cells and

357 purified using Ni-NTA and size-exclusion chromatography (Figure S10). Antigenicity

358 of coronaviral proteins was assessed by binding to immune sera, anti-RBD mAbs

359 CR3022 and 4B, or human and mouse ACE2 (Figure S11). The glycosylation profile

360 of recombinant S proteins (Figure S11) was assessed using mass spectrometry as 361 previously described ${ }^{41}$ by SP3 protein clean up ${ }^{42}$ and trypsin in-solution digestion.

362 Purified peptides were desalted then separated using a two-column chromatography 363 set up comprising a PepMap100 C18 $20 \mathrm{~mm} \times 75 \mu \mathrm{m}$ trap and a PepMap C18 500 $364 \mathrm{~mm} \times 75 \mu \mathrm{m}$ analytical column on Dionex Ultimate 3000 UPLC (ThermoFisher). 365 Samples were concentrated onto the trap column at $5 \mu \mathrm{l} / \mathrm{min}$ with Buffer A $(2 \%$ 366 acetonitrile, $0.1 \%$ formic acid) for $6 \mathrm{~min}$ and infused into a Q-Exactive ${ }^{\mathrm{TM}}$ plus mass 367 spectrometry (ThermoFisher) at $300 \mathrm{nl} / \mathrm{min}$ via the analytical column. $125 \mathrm{~min}$ 368 gradients were used altering the buffer composition from $2 \%$ Buffer B $(80 \%$ 369 acetonitrile, $0.1 \%$ formic acid) to $28 \% \mathrm{~B}$ over $95 \mathrm{~min}$, then from $28 \% \mathrm{~B}$ to $40 \% \mathrm{~B}$ 370 over $10 \mathrm{~min}$, then from $40 \% \mathrm{~B}$ to $100 \% \mathrm{~B}$ over $2 \mathrm{~min}$, the composition was held at $371 \quad 100 \% \mathrm{~B}$ for $3 \mathrm{~min}$, and then dropped to $3 \% \mathrm{~B}$ over $5 \mathrm{~min}$ and held at $3 \% \mathrm{~B}$ for another $37210 \mathrm{~min}$. The Q-Exactive ${ }^{\mathrm{TM}}$ plus Mass Spectrometer was operated in a data-dependent 373 mode automatically switching between the acquisition of a single Orbitrap MS1 scan $374\left(70,000\right.$ resolution, AGC of $\left.3 \times 10^{6}\right)$ followed by 15 data-dependent HCD MS2 events 375 (35,000 resolution; stepped NCE 28, 30, 32; maximum injection time of $125 \mathrm{~ms}$ and 376 AGC of $2 \times 10^{5}$ ) with 30 s dynamic exclusion enabled.

378 The identification of glycoforms were accomplished using Byonic [Protein Metrics, 379 version $3.5 .3^{43}$. MS raw file were searched with a MS1 tolerance of $\pm 5 \mathrm{ppm}$ and a 380 tolerance of \pm 20 ppm was allowed for HCD MS2 scans. Searches were performed 
medRxiv preprint doi: https://doi.org/10.1101/2020.05.17.20104869; this version posted May 21, 2020. The copyright holder for this preprint

(which was not certified by peer review) is the author/funder, who has granted medRxiv a license to display the preprint in perpetuity.

using cysteine carbamidomethylation as a fixed modification, methionine oxidation as a variable modification in addition to allowing $N$-linked glycosylation on asparagine. The default Byonic $N$-linked glycan database, which is composed of 309 mammalian $N$-glycans compiled was used. The proteases specificity was set to full trypsin specificity and a maximum of two miss-cleavage events allowed. Data searched against the expected protein sequence. Search was filtered to a $1 \%$ protein FDR as set in the Byonic parameters with the final results filtered to remove glycopeptide assignments with Byonic score below 300 [double the cut off score suggested by Lee et $\left.a l^{44}\right]$ to remove low quality glycopeptide assignments. Data are available via ProteomeXchange with identifier PXD019163.

\section{ELISA}

Antibody binding to coronavirus S or RBD proteins was tested by ELISA. 96well Maxisorp plates (Thermo Fisher) were coated overnight at $4^{\circ} \mathrm{C}$ with $2 \_\mu \mathrm{g} / \mathrm{mL}$ recombinant S or RBD proteins. After blocking with 1\% FCS in PBS, duplicate wells of serially diluted plasma were added and incubated for two hours at room temperature. Plates were washed prior to incubation with 1:20000 dilution of HRPconjugated anti-human IgG (Sigma) for 1 hour at room temperature. Plates were washed and developed using TMB substrate (Sigma), stopped using sulphuric acid and read at $450 \mathrm{~nm}$. Endpoint titres were calculated as the reciprocal serum dilution giving signal $2 \mathrm{x}$ background using a fitted curve (4 parameter log regression).

\section{ACE2-RBD inhibition ELISA}

An ELISA was performed to measure the ability of plasma antibodies to block interaction between recombinant human ACE2 and RBD proteins. 96-well Maxisorp plates (Thermo Fisher) were coated overnight at $4^{\circ} \mathrm{C}$ with $8 \mu \mathrm{g} / \mathrm{ml}$ of recombinant RBD protein in carbonate-bicarbonate coating buffer (Sigma). After blocking with 
medRxiv preprint doi: https://doi.org/10.1101/2020.05.17.20104869; this version posted May 21, 2020. The copyright holder for this preprint

(which was not certified by peer review) is the author/funder, who has granted medRxiv a license to display the preprint in perpetuity.

406

407

408

409

410

411

412

413

414

415

416

423

424

425

426

427

428

429

430

PBS containing $1 \%$ BSA, duplicate wells of serially diluted plasma (1:25 to 1:1600)

were added and incubated for 1 hour at room temperature. Plates were then incubated

with $1.5 \mu \mathrm{g} / \mathrm{ml}$ of biotinylated recombinant ACE2 protein for 1 hour at room temperature followed by incubation with HRP-conjugated streptavidin (Thermo Fisher Scientific) for 1 hour at room temperature. Plates were developed with TMB substrate (Sigma), stopped with $0.15 \mathrm{M}$ sulphuric acid and read at $450 \mathrm{~nm}$.

\section{Microneutralisation Assay}

SARS-CoV-2 isolate CoV/Australia/VIC01/2020 ${ }^{45}$ was passaged in Vero cells and stored at $-80 \mathrm{C}$. Plasma was heat-inactivated at $56^{\circ} \mathrm{C}$ for $30 \mathrm{~min}$. Plasma was seriallydiluted 1:20 to $1: 10240$ before addition of 100 TCID $_{50}$ of SARS-CoV-2 in $\mathrm{MEM} / 0.5 \% \mathrm{BSA}$ and incubation at room temperature for 1 hour. Residual virus infectivity in the plasma/virus mixtures was assessed in quadruplicate wells of Vero cells incubated in serum-free media containing $1 \mu \mathrm{g} / \mathrm{ml}$ TPCK trypsin at $37^{\circ} \mathrm{C} / 5 \%$ $\mathrm{CO} 2$; viral cytopathic effect was read on day 5 . The neutralising antibody titre is calculated using the Reed/Muench method as previously described ${ }^{21,22}$.

\section{Flow cytometric detection of SARS-CoV-2 reactive B cells}

Probes for delineating SARS-CoV-2 S-specific B cells within cryopreserved human PBMC were generated by sequential addition of streptavidin-PE (Thermofisher) to trimeric S protein biotinylated using recombinant Bir-A (Avidity). Biotinylated SARS-CoV RBD was similarly conjugated to streptavidin-BV421 (BD). SARS-CoV2 RBD protein was directly labelled to APC using an APC Conjugation Lightninglink kit (Abcam). Cells were stained with Aqua viability dye (Thermofisher). Monoclonal antibodies for surface staining included: CD19-ECD (J3-119) (Beckman 
medRxiv preprint doi: https://doi.org/10.1101/2020.05.17.20104869; this version posted May 21 , 2020. The copyright holder for this preprint

(which was not certified by peer review) is the author/funder, who has granted medRxiv a license to display the preprint in perpetuity.

431 Coulter), CD20 Alexa700 (2H7), IgM-BUV395 (G20-127), CD21-BUV737 (B-ly4),

432 IgD-Cy7PE (IA6-2), IgG-BV786 (G18-145) (BD), CD14-BV510 (M5E2), CD3-

433 BV510 (OKT3), CD8a-BV510 (RPA-T8), CD16-BV510 (3G8), CD10-BV510

434 (HI10a), CD27-BV605 (O323) (Biolegend)._Cells were washed, fixed with 1\%

435 formaldehyde (Polysciences) and acquired on a BD LSR Fortessa or BD Aria II.

Flow cytometric detection of antigen-specific cTFH and CD4 T cells

438 Cryopreserved human PBMC were thawed and rested for four hours at $37^{\circ} \mathrm{C}$. Cells

439 were cultured in 96-well plates at $1 \times 10^{6}$ cells/well and stimulated for 20 hours with

$4405 \mu \mathrm{g} / \mathrm{mL}$ of protein (BSA, SARS-CoV-2 S, SARS-CoV-2 RBD, HKU1 S). Selected

441 donors were also stimulated with $\mathrm{SEB}(5 \mu \mathrm{g} / \mathrm{mL})$ as a positive control. Following

442 stimulation, cells were washed, stained with Live/dead Blue viability dye

443 (ThermoFisher), and a cocktail of monoclonal antibodies: CD27 BUV737 (L128),

444 CCR7 Alexa700 (150503), CD45RA PeCy7 (HI100), CD20 BUV805 (2H7), CD14

445 BUV395 (MOP9) (BD Biosciences), CD3 BV510 (SK7), CD4 BV605 (RPA-T4),

446 CD8 BV650 (RPA-T8), CD25 APC (BC96), OX-40 PerCP-Cy5.5 (ACT35), PD-1

447 BV421 (EH12.2H7), CCR6 BV785 (G034E3), CXCR3 Pe-Dazzle594 (G02H57)

448 (Biolegend), and CXCR5 PE (MU5UBEE, ThermoFisher). Cells were washed, fixed

449 with $1 \%$ formaldehyde and acquired on a BD LSR Fortessa using BD FACS Diva.

\section{Statistical Analyses}

451 Grouped data are generally presented as median +/- IQR, with groups compared by

452 Wilcoxon or Mann-Whitney $U$ tests using Prism 8.0 (Graphpad). Pairwise

453 correlations were assessed using Spearmans tests in Prism 8.0 (Graphpad). A

454 multiple linear regression was used to determine which factors can be used to predict

455 the values of microneutralization across 41 patients. A backward model selection 
medRxiv preprint doi: https://doi.org/10.1101/2020.05.17.20104869; this version posted May 21, 2020. The copyright holder for this preprint

(which was not certified by peer review) is the author/funder, who has granted medRxiv a license to display the preprint in perpetuity.

All rights reserved. No reuse allowed without permission.

456

457

458

459

460

461

462

463

464

465

466

467

468

469

470

471

472

473

474

475

476

477

\section{8}

479

480

481

method was used by first fitting a model with all variables of interest, and gradually

removing one variable with the least significant $\mathrm{p}$ value. For each step, the nested $\mathrm{F}$ test was used to compare the models (ie: if the removed variable contributed significantly to the fit). This procedure was stopped when a model with only significant predictors was obtained. Confirmatory forward selection methods were also employed, arriving at the same final model. This analysis was performed using the $l m$ function in $R(\mathrm{v} 3 \cdot 6.3)$.

Spearman correlation matrix was calculated using the rcorr function in $R$ (v3.6.3). Principal component analysis was performed in $R$ (v3.6.3) using the princomp function by first scaling the variables to have a unit variance. Throughout the manuscript, significance was defined as $\mathrm{p}<0.05$.

\section{Competing interests}

The authors declare no competing interests.

\section{Authors' contributions}

JAJ, HXT, WSL, SJK and AKW designed the study and experiments; JAJ, HXT, WSL, AR, HGK, KW, RE, HEK, CJB, FLM, NAG, PP, MD, NES and AKW performed experiments; WHT, NAG, DIG, KS contributed unique reagents; JAJ, HXT, WSL, AR, KS, MPD, SJK and AKW analysed the experimental data; JAJ, HXT, WSL, AR, MPD, SJK and AKW wrote the manuscript. All authors reviewed the manuscript.

\section{Acknowledgements}

We thank the generous participation of the trial subjects for providing samples. The

SARS-CoV-2 RBD expression plasmids were kindly provided by Florian Krammer,

Mt Sinai School of Medicine, NY, USA. The human and mouse ACE2 expression 
medRxiv preprint doi: https://doi.org/10.1101/2020.05.17.20104869; this version posted May 21, 2020. The copyright holder for this preprint (which was not certified by peer review) is the author/funder, who has granted medRxiv a license to display the preprint in perpetuity. All rights reserved. No reuse allowed without permission.

plasmids were kindly provided by Merlin Thomas, Monash University, Australia. We acknowledge the Melbourne Cytometry Platform (Melbourne Brain Centre node) for provision of flow cytometry services. We thank the Melbourne Mass Spectrometry and Proteomics Facility of The Bio21 Molecular Science and Biotechnology Institute at The University of Melbourne for the support of mass spectrometry analysis. This study was supported by the ARC Centre of Excellence in Convergent Bio-Nano Science and Technology (SJK), an NHMRC program grant APP1149990 (SJK), NHMRC project grant GNT1162760 (AKW), and the Jack Ma Foundation (DIG, NAG). WHT is a Howard Hughes Medical Institute-Wellcome Trust International Research Scholar (208693/Z/17/Z). JAJ, DIG, MPD, WHT, SJK and AKW are supported by NHMRC fellowships.

\section{References}

1. Li, F. Structure, Function, and Evolution of Coronavirus Spike Proteins. Annu Rev Virol 3, 237-261 (2016).

2. Hoffmann, M., et al. SARS-CoV-2 Cell Entry Depends on ACE2 and TMPRSS2 and Is Blocked by a Clinically Proven Protease Inhibitor. Cell 181, 271-280.e278 (2020).

3. Yan, R., et al. Structural basis for the recognition of SARS-CoV-2 by fulllength human ACE2. Science (New York, N.Y.) 367, 1444-1448 (2020).

4. Lan, J., et al. Structure of the SARS-CoV-2 spike receptor-binding domain bound to the ACE2 receptor. Nature (2020).

5. Jiang, S., Hillyer, C. \& Du, L. Neutralizing Antibodies against SARS-CoV-2 and Other Human Coronaviruses. Trends in immunology 41, 355-359 (2020).

6. Tian, X., et al. Potent binding of 2019 novel coronavirus spike protein by a SARS coronavirus-specific human monoclonal antibody. Emerg Microbes Infect 9, 382-385 (2020).

7. Yuan, M., et al. A highly conserved cryptic epitope in the receptor binding domains of SARS-CoV-2 and SARS-CoV. Science (New York, N.Y.) 368, 630-633 (2020).

8. Pinto, D., et al. Structural and functional analysis of a potent sarbecovirus neutralizing antibody. bioRxiv, 2020.2004.2007.023903 (2020).

9. Ju, B., et al. Potent human neutralizing antibodies elicited by SARS-CoV-2 infection. bioRxiv, 2020.2003.2021.990770 (2020).

10. Chi, X., et al. A potent neutralizing human antibody reveals the N-terminal domain of the Spike protein of SARS-CoV-2 as a site of vulnerability. bioRxiv, 2020.2005.2008.083964 (2020).

11. Wang, L., et al. Importance of Neutralizing Monoclonal Antibodies Targeting Multiple Antigenic Sites on the Middle East Respiratory Syndrome 
medRxiv preprint doi: https://doi.org/10.1101/2020.05.17.20104869; this version posted May 21, 2020. The copyright holder for this preprint (which was not certified by peer review) is the author/funder, who has granted medRxiv a license to display the preprint in perpetuity. All rights reserved. No reuse allowed without permission.

Coronavirus Spike Glycoprotein To Avoid Neutralization Escape. Journal of virology 92(2018).

12. Widjaja, I., et al. Towards a solution to MERS: protective human monoclonal antibodies targeting different domains and functions of the MERS-coronavirus spike glycoprotein. Emerg Microbes Infect 8, 516-530 (2019).

13. Sui, J., et al. Potent neutralization of severe acute respiratory syndrome (SARS) coronavirus by a human $\mathrm{mAb}$ to $\mathrm{S} 1$ protein that blocks receptor association. Proceedings of the National Academy of Sciences of the United States of America 101, 2536-2541 (2004).

14. Lip, K.M., et al. Monoclonal antibodies targeting the HR2 domain and the region immediately upstream of the HR2 of the $\mathrm{S}$ protein neutralize in vitro infection of severe acute respiratory syndrome coronavirus. Journal of virology 80, 941-950 (2006).

15. Amanat, F. \& Krammer, F. SARS-CoV-2 Vaccines: Status Report. Immunity 52, 583-589 (2020).

16. Thanh Le, T., et al. The COVID-19 vaccine development landscape. Nature reviews. Drug discovery 19, 305-306 (2020).

17. Gao, Q., et al. Rapid development of an inactivated vaccine candidate for SARS-CoV-2. Science (New York, N.Y.) (2020).

18. Lv, H., et al. Cross-reactive antibody response between SARS-CoV-2 and SARS-CoV infections. bioRxiv, 2020.2003.2015.993097 (2020).

19. Zhou, W., Wang, W., Wang, H., Lu, R. \& Tan, W. First infection by all four non-severe acute respiratory syndrome human coronaviruses takes place during childhood. BMC infectious diseases 13, 433 (2013).

20. Okba, N.M.A., et al. Severe Acute Respiratory Syndrome Coronavirus 2Specific Antibody Responses in Coronavirus Disease 2019 Patients. Emerg Infect Dis 26(2020).

21. Subbarao, K., et al. Prior infection and passive transfer of neutralizing antibody prevent replication of severe acute respiratory syndrome coronavirus in the respiratory tract of mice. Journal of virology 78, 3572-3577 (2004).

22. Houser, K.V., et al. Prophylaxis With a Middle East Respiratory Syndrome Coronavirus (MERS-CoV)-Specific Human Monoclonal Antibody Protects Rabbits From MERS-CoV Infection. The Journal of infectious diseases 213, 1557-1561 (2016).

23. Koutsakos, M., et al. Circulating $\mathrm{T}(\mathrm{FH})$ cells, serological memory, and tissue compartmentalization shape human influenza-specific B cell immunity. Science translational medicine 10(2018).

24. Lau, D., et al. Low CD21 expression defines a population of recent germinal center graduates primed for plasma cell differentiation. Science immunology 2(2017).

25. Ou, X., et al. Characterization of spike glycoprotein of SARS-CoV-2 on virus entry and its immune cross-reactivity with SARS-CoV. Nature communications 11, 1620 (2020).

26. Crotty, S. T Follicular Helper Cell Biology: A Decade of Discovery and Diseases. Immunity 50, 1132-1148 (2019).

27. Brenna, E., et al. CD4(+) T Follicular Helper Cells in Human Tonsils and Blood Are Clonally Convergent but Divergent from Non-Tfh CD4(+) Cells. Cell reports 30, 137-152.e135 (2020). 
medRxiv preprint doi: https://doi.org/10.1101/2020.05.17.20104869; this version posted May 21, 2020. The copyright holder for this preprint (which was not certified by peer review) is the author/funder, who has granted medRxiv a license to display the preprint in perpetuity.

602

603

604

605

606

607

608

609

610

611

612

613

614 615

28. Morita, R., et al. Human blood CXCR5(+)CD4(+) T cells are counterparts of $\mathrm{T}$ follicular cells and contain specific subsets that differentially support antibody secretion. Immunity 34, 108-121 (2011).

29. Dan, J.M., et al. A Cytokine-Independent Approach To Identify AntigenSpecific Human Germinal Center T Follicular Helper Cells and Rare AntigenSpecific CD4+ T Cells in Blood. Journal of immunology (Baltimore, Md. : 1950) 197, 983-993 (2016).

30. Bentebibel, S.E., et al. Induction of ICOS+CXCR3+CXCR5+ TH cells correlates with antibody responses to influenza vaccination. Science translational medicine 5, 176ra132 (2013).

31. Koutsakos, M., Nguyen, T.H.O. \& Kedzierska, K. With a Little Help from T Follicular Helper Friends: Humoral Immunity to Influenza Vaccination. Journal of immunology (Baltimore, Md. : 1950) 202, 360-367 (2019).

32. Brouwer, P., et al. Potent neutralizing antibodies from COVID-19 patients define multiple targets of vulnerability. bioRxiv, 2020.2005.2012.088716 (2020).

33. Tan, H.X., et al. Subdominance and poor intrinsic immunogenicity limit humoral immunity targeting influenza HA stem. The Journal of clinical investigation 129, 850-862 (2019).

34. Farooq, F., et al. Circulating follicular T helper cells and cytokine profile in humans following vaccination with the rVSV-ZEBOV Ebola vaccine. Scientific reports 6, 27944 (2016).

35. Bentebibel, S.E., et al. ICOS(+)PD-1(+)CXCR3(+) $\mathrm{T}$ follicular helper cells contribute to the generation of high-avidity antibodies following influenza vaccination. Scientific reports 6, 26494 (2016).

36. Niessl, J., et al. Persistent expansion and Th1-like skewing of HIV-specific circulating $\mathrm{T}$ follicular helper cells during antiretroviral therapy. EBioMedicine 54, 102727 (2020).

37. Zhang, J., et al. Circulating CXCR3(+) Tfh cells positively correlate with neutralizing antibody responses in HCV-infected patients. Scientific reports $\mathbf{9}$, 10090 (2019).

38. Braun, J., et al. Presence of SARS-CoV-2 reactive T cells in COVID-19 patients and healthy donors. medRxiv, 2020.2004.2017.20061440 (2020).

39. Wrapp, D., et al. Cryo-EM structure of the 2019-nCoV spike in the prefusion conformation. Science (New York, N.Y.) 367, 1260-1263 (2020).

40. Amanat, F., et al. A serological assay to detect SARS-CoV-2 seroconversion in humans. Nature medicine (2020).

41. Lopez, E., et al. Low pH Exposure During Immunoglobulin G Purification Methods Results in Aggregates That Avidly Bind Fcy Receptors: Implications for Measuring Fc Dependent Antibody Functions. Frontiers in immunology 10, 2415 (2019).

42. Hughes, C.S., et al. Single-pot, solid-phase-enhanced sample preparation for proteomics experiments. Nat Protoc 14, 68-85 (2019).

43. Bern, M., Kil, Y.J. \& Becker, C. Byonic: advanced peptide and protein identification software. Curr Protoc Bioinformatics Chapter 13, Unit13.20 (2012).

44. Lee, L.Y., et al. Toward Automated N-Glycopeptide Identification in Glycoproteomics. Journal of proteome research 15, 3904-3915 (2016). 
medRxiv preprint doi: https://doi.org/10.1101/2020.05.17.20104869; this version posted May 21,2020 . The copyright holder for this preprint (which was not certified by peer review) is the author/funder, who has granted medRxiv a license to display the preprint in perpetuity.

All rights reserved. No reuse allowed without permission.

616

617

618

619
45. Caly, L., et al. Isolation and rapid sharing of the 2019 novel coronavirus (SARS-CoV-2) from the first patient diagnosed with COVID-19 in Australia. Med J Aust (2020). 
A

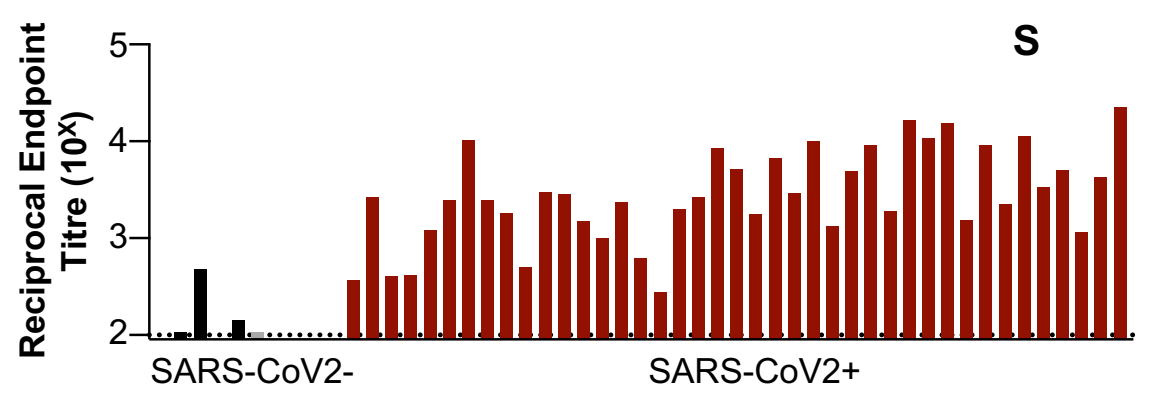

B

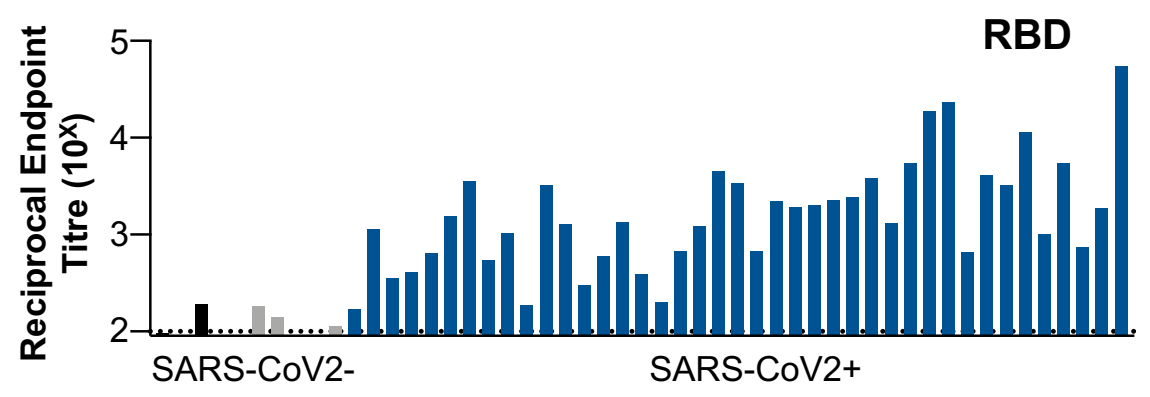

C

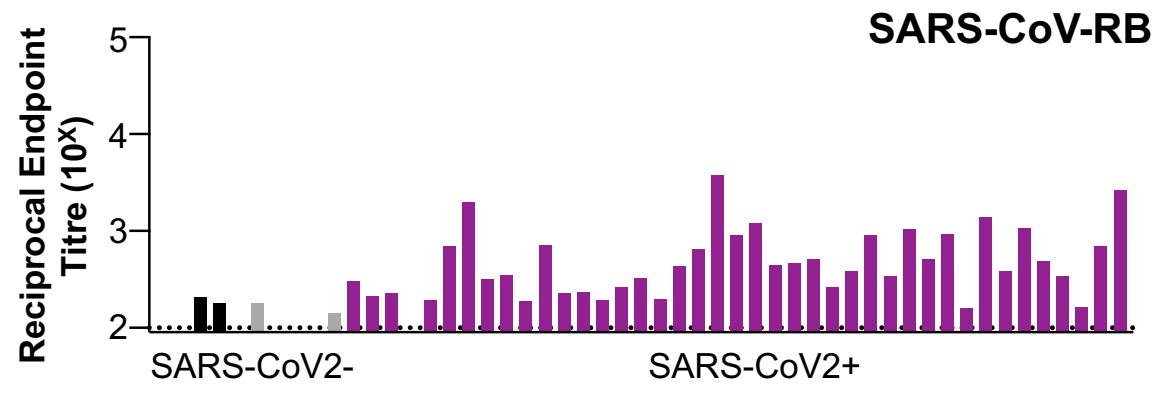

D $\begin{array}{lll} & 5 & 5 \\ & & \text { HKU1 }\end{array}$

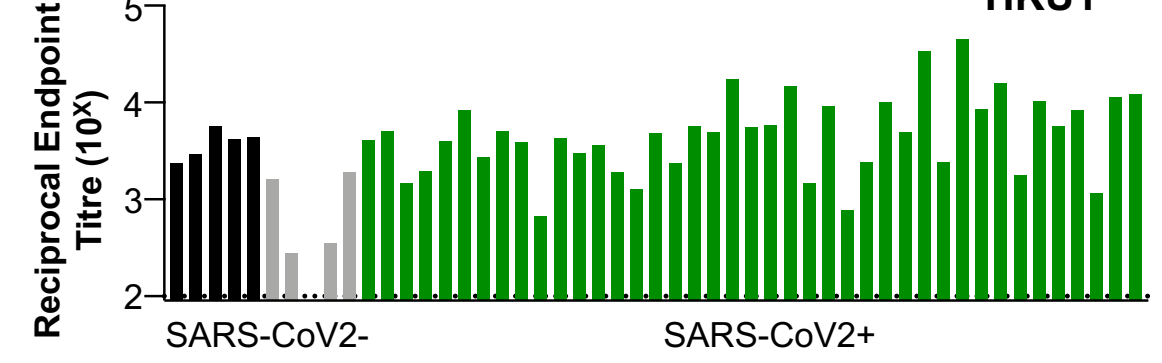

E

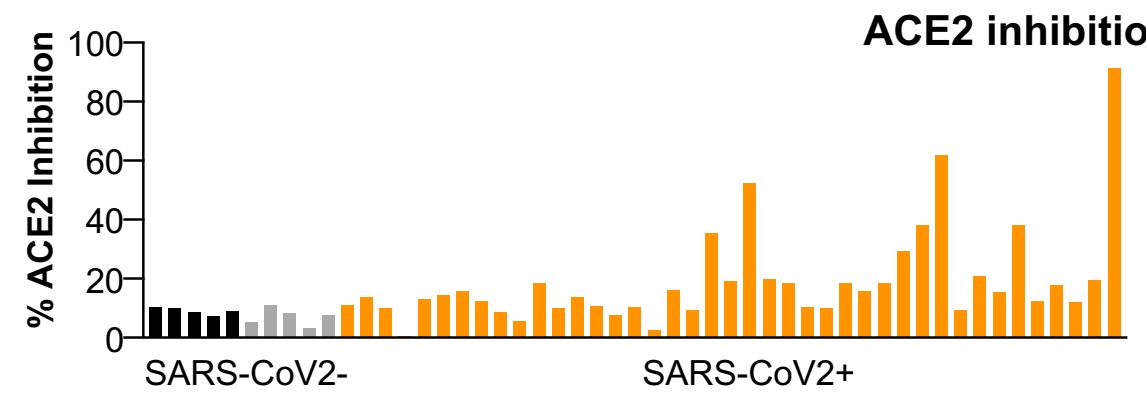

$\mathbf{F}$

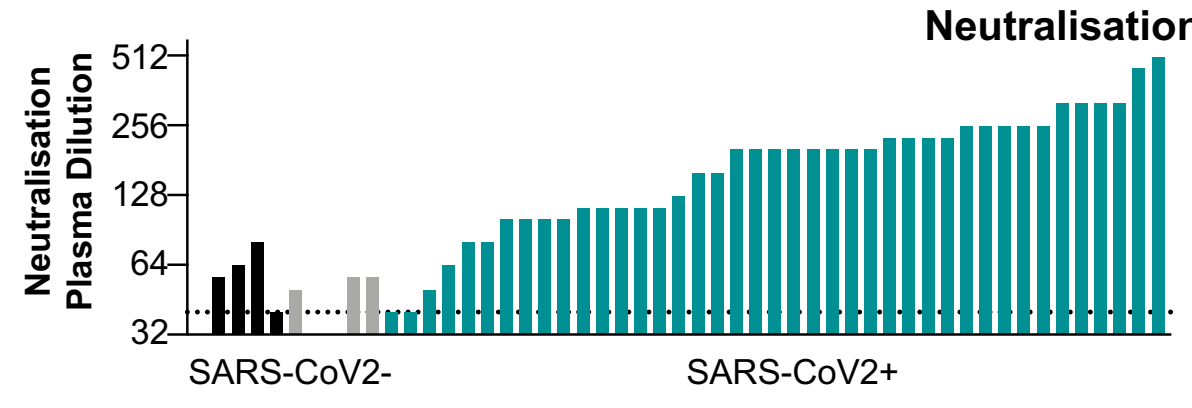




\section{Figure 1. Serological responses to COVID19.}

Plasma samples from subjects recovered from SARS-CoV-2 infection $(\mathrm{N}=41)$ and healthy controls $(\mathrm{N}=10$, black/grey bars) were screened by ELISA for reactivity against $\mathrm{S}$ recombinant proteins from (A) SARS-CoV-2 S, (B) SARS-CoV-2 RBD, (C) SARS-CoV RBD and (D) HCoV-HKU1. (E) The capacity of plasma antibodies to inhibit the interaction of RBD with human ACE2 was tested in an ELISA format at a plasma dilution of 1:25. (F) Neutralisation activity in the plasma was assessed using a microneutralisation assay. Data represent individual responses for each subject, and column order for all figures is conserved and stratified on the basis of plasma neutralisation activity. SARS-CoV-2 negative donors were stratified based on HCoV-HKU1 serological titres (black, high titres; grey, low titres). 
Figure 2. Frequency and phenotype of SARS-CoV-2-specific B cells following infection

(A) Co-staining class-switched B cells $\left(\mathrm{CD} 19^{+} \mathrm{IgD} \mathrm{D}^{-}\right)$with SARS-CoV-2 spike and RBD probes allows resolution of antigen-specific cells in subjects previously infected with SARS-CoV-2 relative to uninfected controls. (B) Frequencies of spike ${ }^{+} \mathrm{RBD}^{-}$, spike ${ }^{+} \mathrm{RBD}^{+}$and spike ${ }^{+} \mathrm{RBD}^{-} \mathrm{B}$ cells as a proportion of $\mathrm{CD}^{+} 9^{+} \mathrm{IgD}^{-} \mathrm{B}$ cells in PBMC from subjects previously infected with SARS-CoV-2 $(\mathrm{N}=41)$ and uninfected controls $(\mathrm{N}=10)$. (C) Isotype distribution of spike ${ }^{+} \mathrm{RBD}^{-}$and spike $\mathrm{RBD}^{+} \mathrm{CD}^{+} 9^{+} \mathrm{IgD}^{-} \mathrm{B}$ cells; n.d - not detected due to absent probe ${ }^{+}$cells. (D) Co-staining spike ${ }^{+} \mathrm{CD} 19^{+} \mathrm{IgD}^{-} \mathrm{B}$ cells with SARS-CoV-2 and SARS-CoV RBD probes allows discrimination of cross-reactive specificities versus those unique to SARS-CoV-2. (E) Frequency of SARS-CoV$2 \mathrm{RBD}^{+} / \mathrm{SARS}-\mathrm{CoV} \mathrm{RBD}^{-}$cells as a proportion of spike ${ }^{+} \mathrm{CD} 19^{+} \operatorname{IgD}-\mathrm{IgG}^{+} \mathrm{B}$ cells and their correlation (Spearman) to (F) ACE2/RBD binding inhibition and (G) neutralising activity in plasma. 


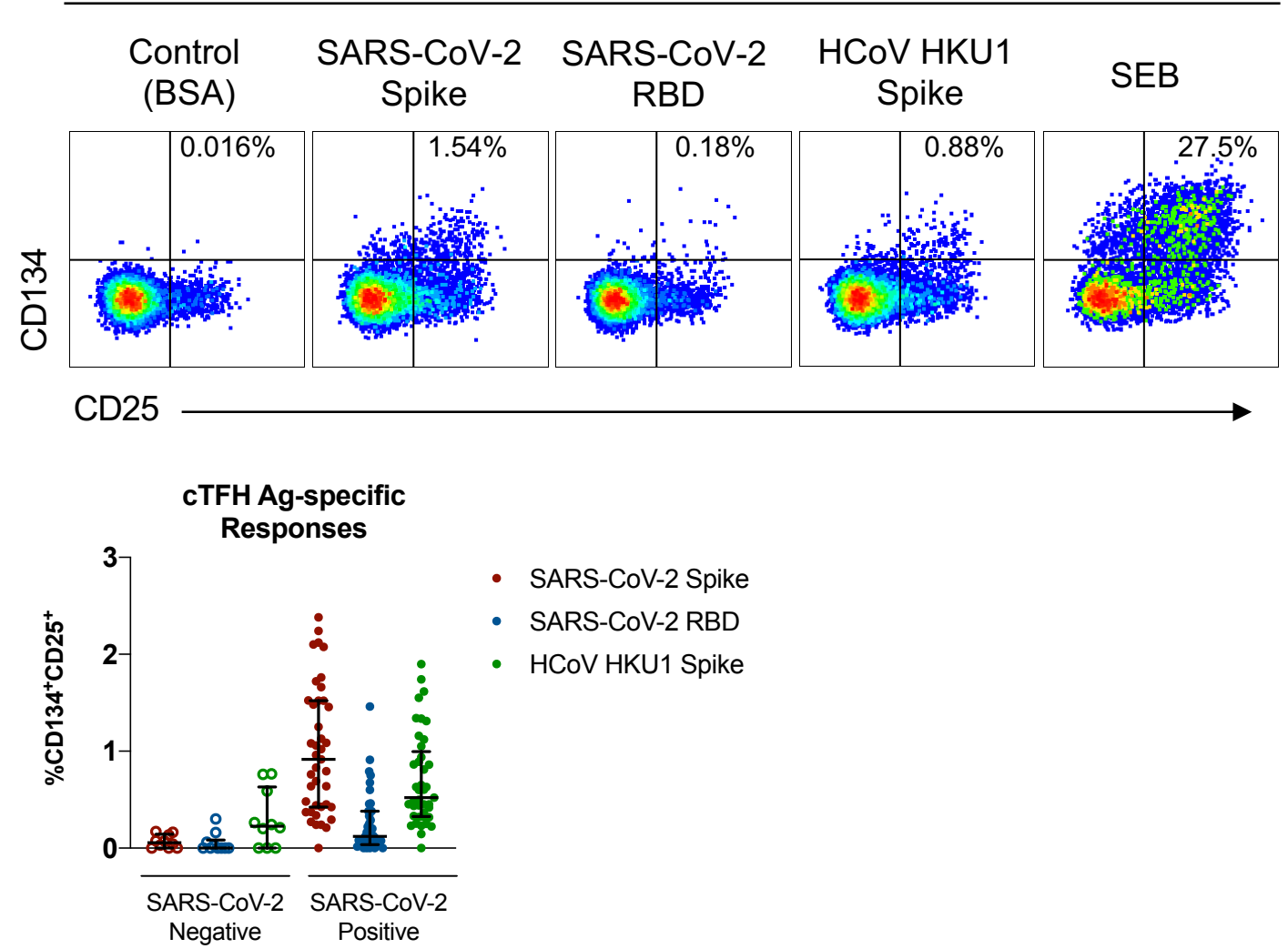

C

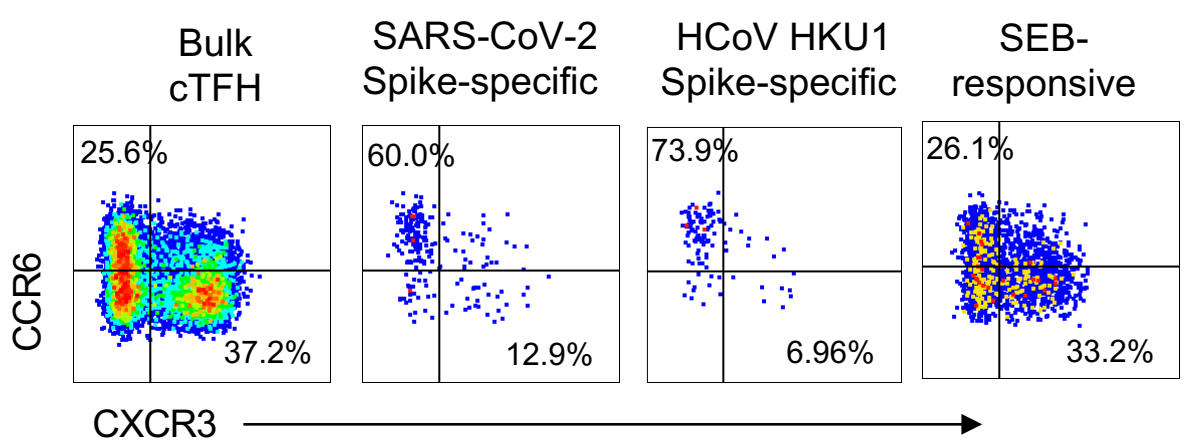

D

Phenotype of cTFH populations

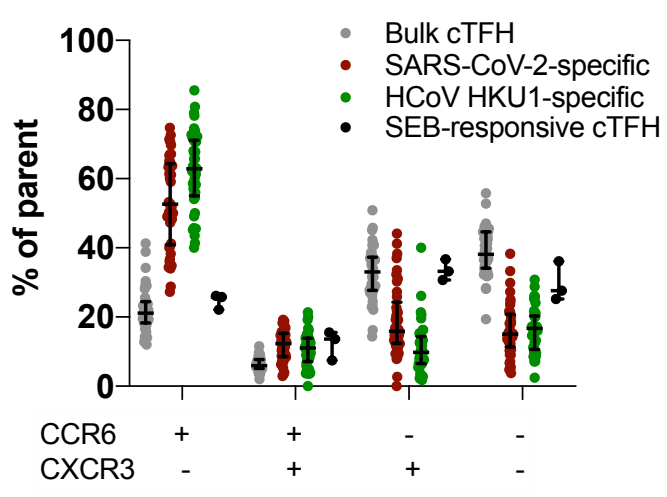


Figure 3. Specificity of cTFH responses to coronavirus spike proteins

(A) Representative staining of CD25 and CD134 co-expression on cTFH $\left(\mathrm{CD}^{+}{ }^{+} \mathrm{CD} 4^{+} \mathrm{CD} 45 \mathrm{RA}-\mathrm{CXCR}^{+}\right)$cells following stimulation with $5 \mu \mathrm{g} / \mathrm{mL}$ BSA (negative control), SARS-CoV-2 Spike, SARS-CoV-2 RBD or HCoV HKU1 protein, or SEB (positive control). (B) Antigen-specific cTFH ( $\mathrm{n}=10$ SARS-CoV-2 negative, $\mathrm{n}=41$ SARS-CoV-2 positive donors) frequencies were calculated as the proportion of $\mathrm{CD} 25^{+} \mathrm{CD} 134^{+} \mathrm{cTFH}$ cells in each stimulation condition after background subtraction using the negative control. (C) Representative expression of CCR6 and CXCR3 on bulk cTFH, SARS-CoV-2 Spikespecific, HCoV HKU1 Spike-specific or SEB-responsive $\left(\mathrm{CD} 25^{+} \mathrm{OX}-40^{+}\right)$cTFH. (D) Quantification of $\mathrm{CCR}^{+}{ }^{+} \mathrm{CXCR} 3^{-}, \mathrm{CCR}^{+}{ }^{+} \mathrm{CXCR}^{+}{ }^{+}, \mathrm{CCR}^{-} \mathrm{CXCR}^{+}$or $\mathrm{CCR}^{-} \mathrm{CXCR} 3^{-}$ cTFH populations among SARS-CoV-2 positive donors $(n=41)$. 
B
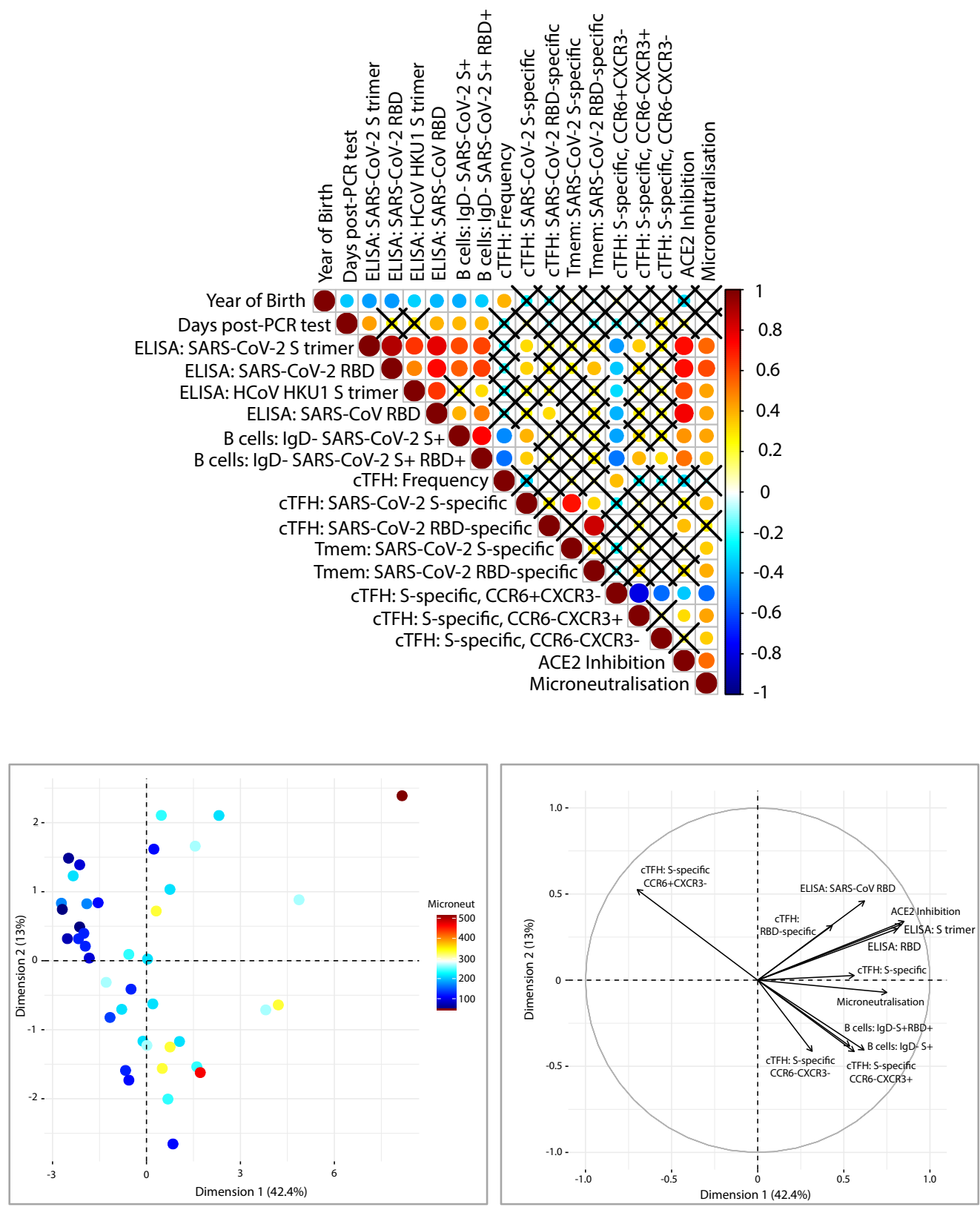

C
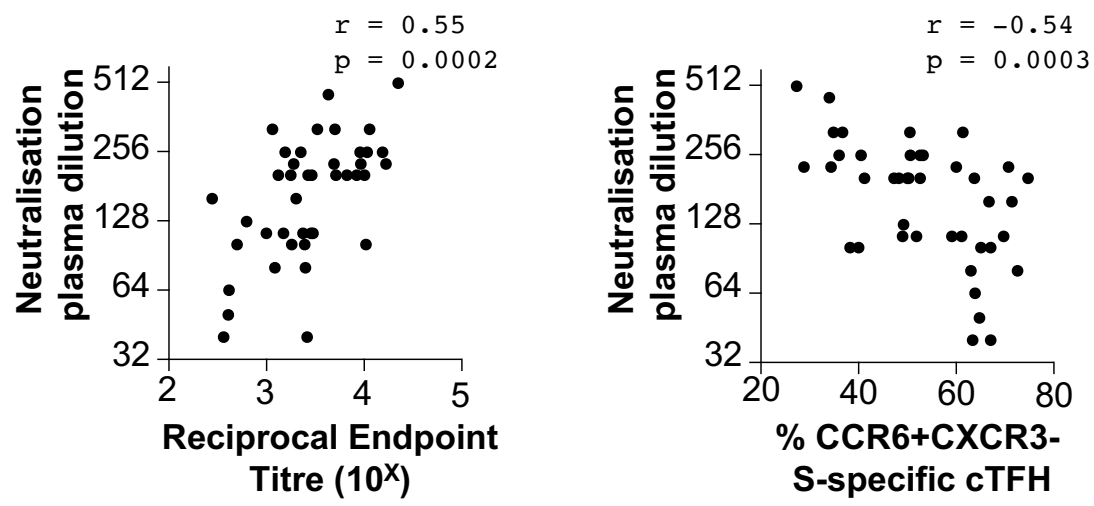


\section{Figure 4. Predictors of plasma neutralisation activity}

(A) Co-correlation matrix of subject characteristics, infection and immunological dynamics in subjects recovered from SARS-CoV-2 infection. (B) Principle component analysis of immune parameters showing individuals coloured in proportion to plasma neutralisation titres. (C) Spearman correlation of the plasma neutralisation activity with S-specific antibody titres and the proportion of $\mathrm{CCR}^{+}{ }^{+} \mathrm{CXCR} 3^{-}$phenotype with the S-specific cTFH population. 
SUPPLEMENTARY FIGURES 


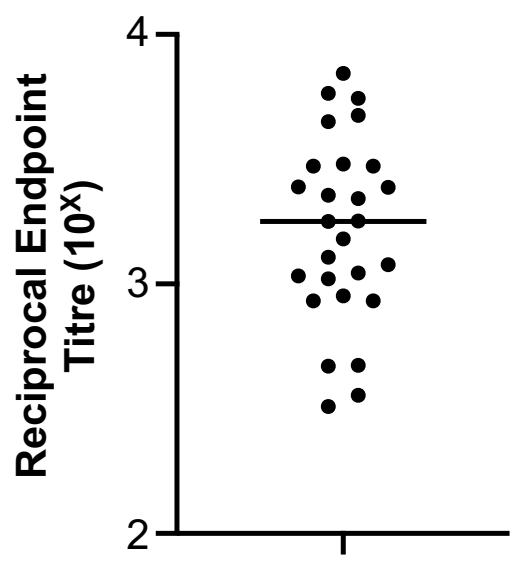

Figure S1. Pre-screen of HCoV-HKU1 serum endpoint titres among a cohort of healthy subjects $(\mathrm{N}=27)$ bled prior to the SARS-CoV-2 pandemic 
A
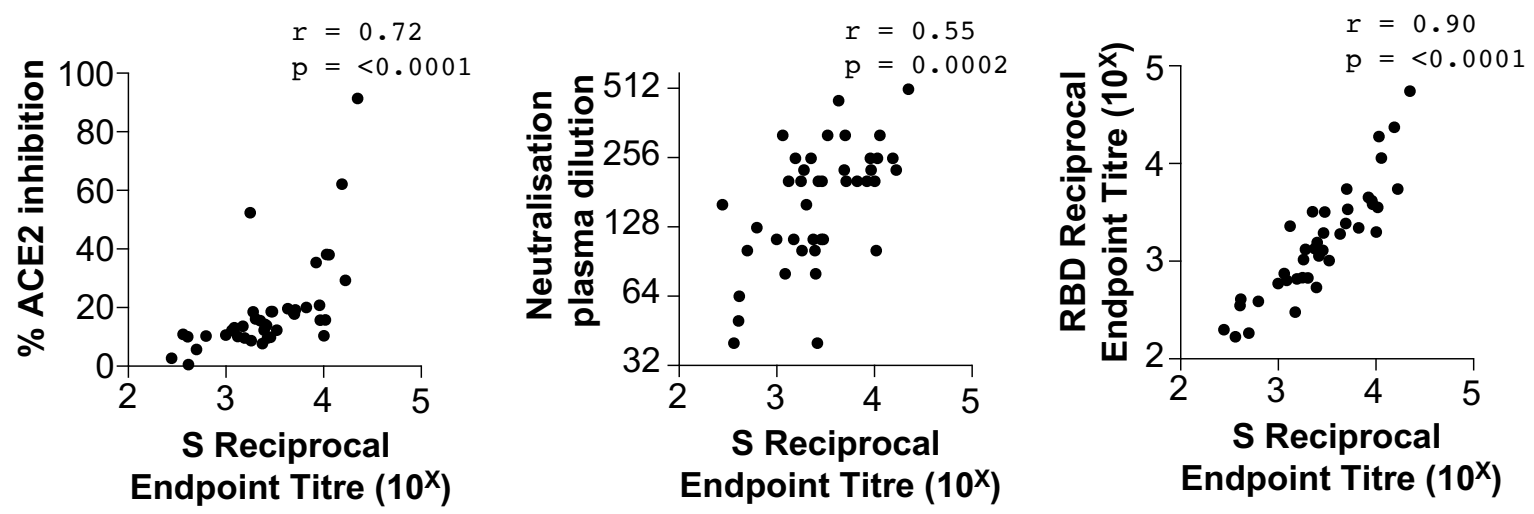

B
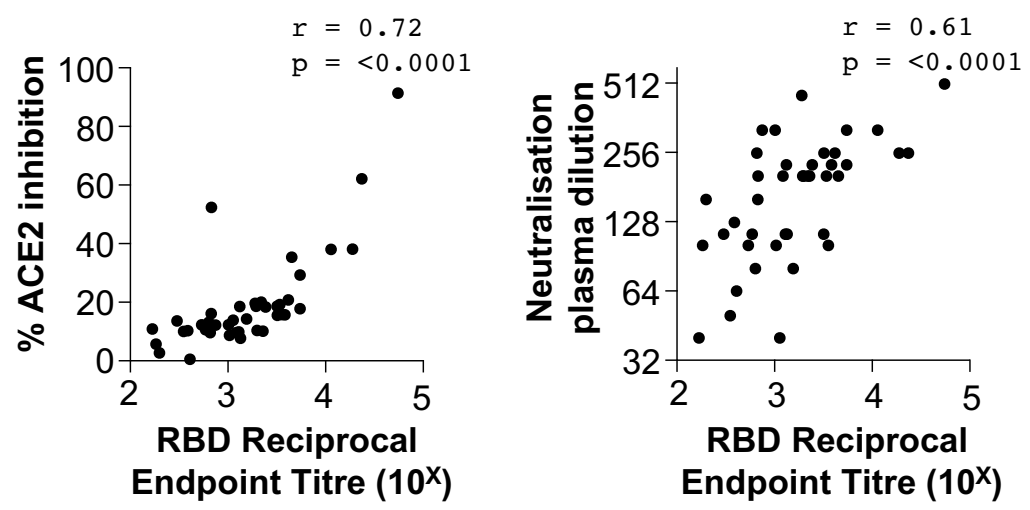

C

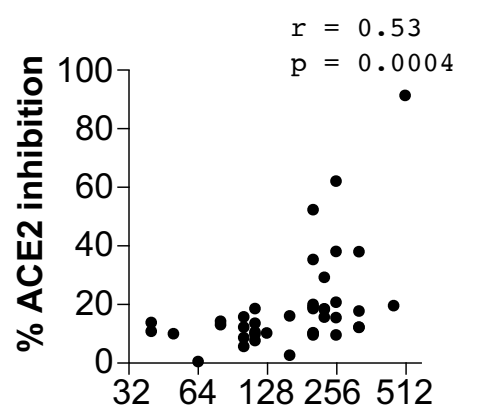

Neutralisation

plasma dilution

Figure S2. Correlations between antibody binding titres, ACE2/RBD binding inhibition and neutralisation activity in plasma from subjects recovered from SARSCoV-2 infection

(A) Correlation between endpoint titres of S-specific plasma antibody and the extent of ACE2/RBD binding inhibition, plasma neutralisation titres or RBD-specific plasma antibody. (B) Correlation between endpoint titres of RBD-specific plasma antibody and the extent of ACE2/RBD binding inhibition or plasma neutralisation titres. (C) Correlation between plasma ACE2/RBD binding inhibition and neutralisation activity. 


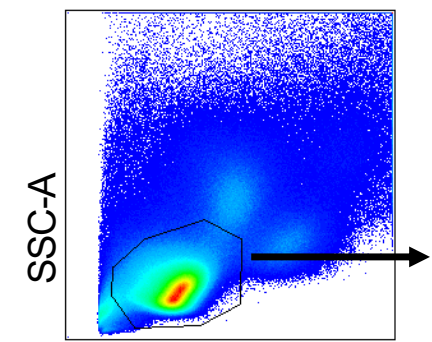

FSC-A

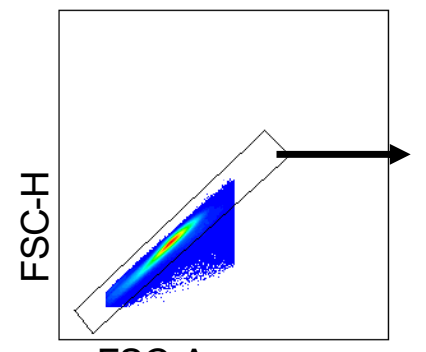

FSC-A
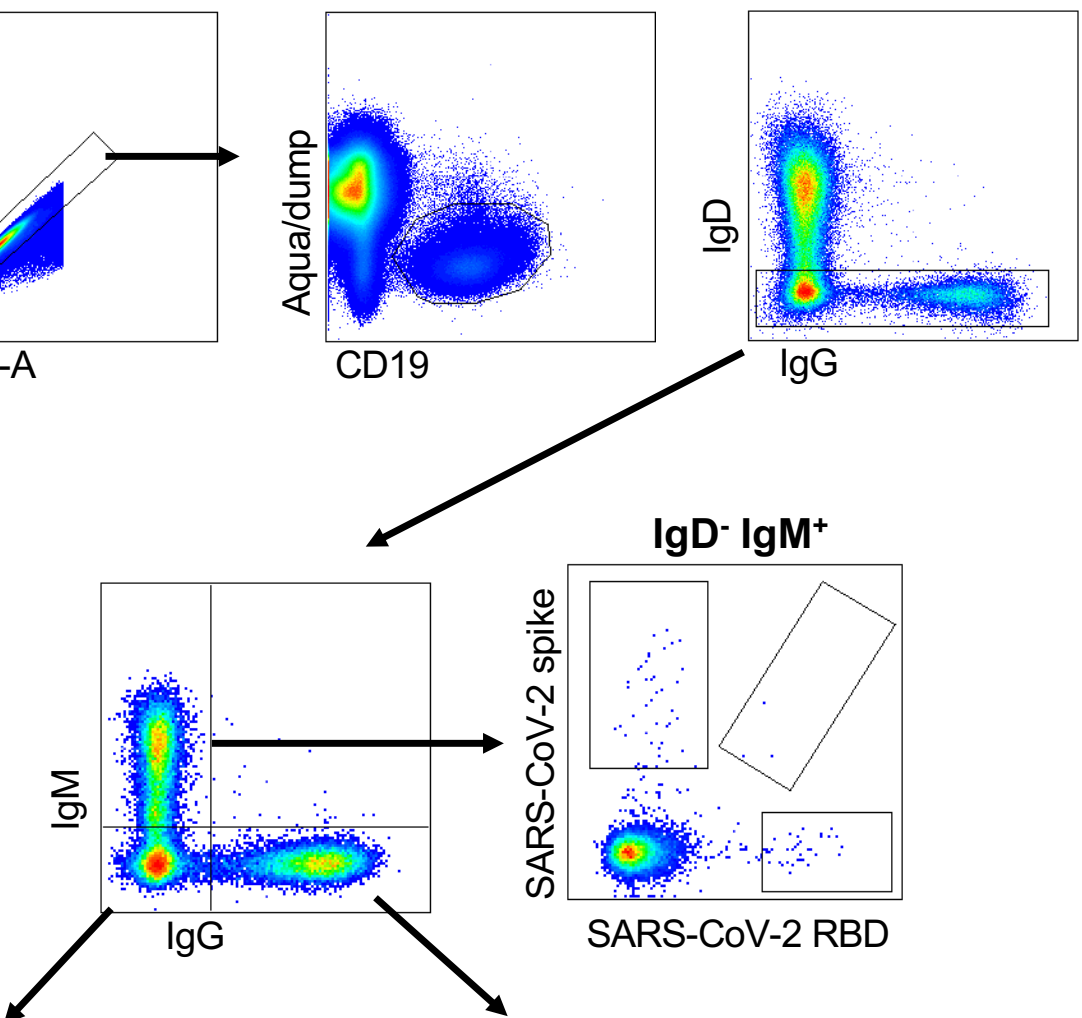

$\lg D^{-} \lg M^{+}$

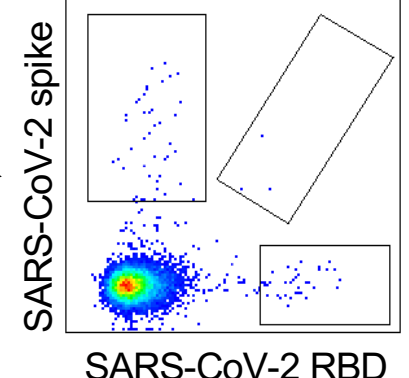

SARS-CoV-2 RBD

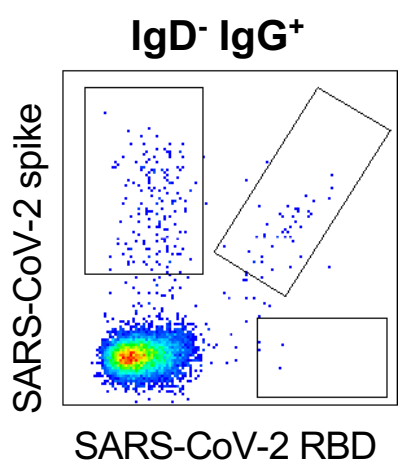

Figure S3. Gating strategy for resolving antigen-specific $B$ cells and surface isotypes Lymphocytes were identified by FSC-A vs SSC-A gating, followed by doublet exclusion (FSC-A vs FSC-H), and gating on live $\mathrm{CD} 19^{+}$B cells. Class-switched B cells were identified as $\mathrm{IgD}^{-}$, and surface istoype resolved by staining for $\operatorname{IgM}$ or $\mathrm{IgG}$, with the double negative population $\left(\operatorname{IgM}^{-} / \operatorname{IgG}^{-}\right)$previously established as predominantly $\operatorname{IgA}$. Binding to SARS-CoV-2 spike (S) and/or SARS-CoV-2 RBD probes was assessed for each population. 
SARS-CoV-2

Negative
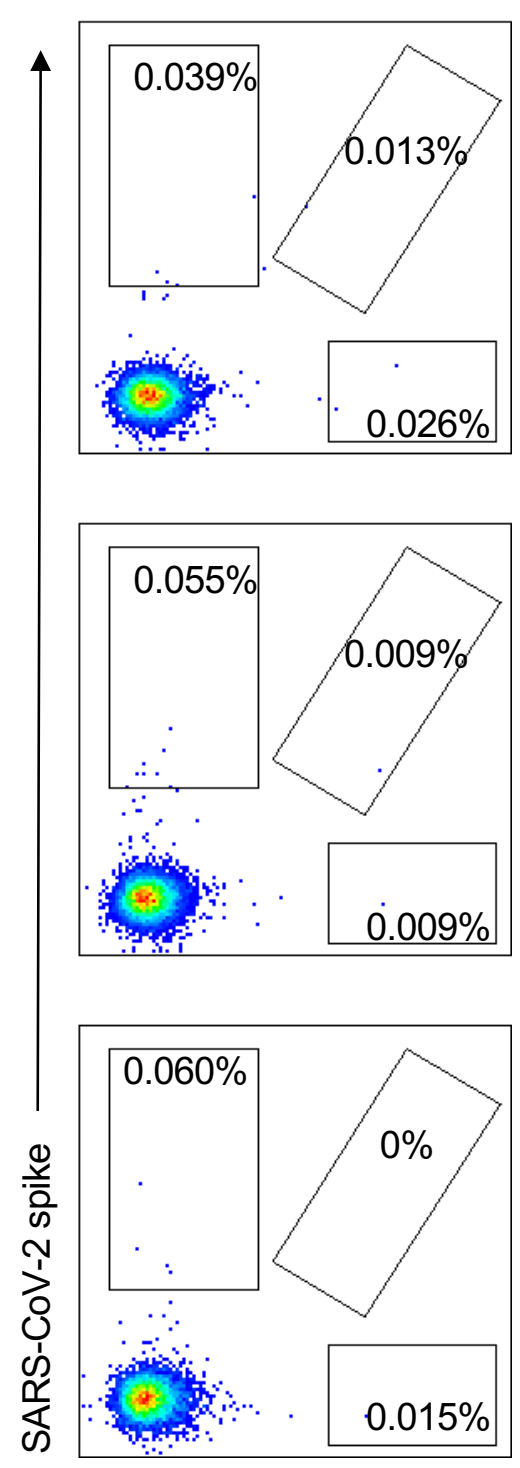

SARS-CoV-2 RBD
SARS-CoV-2

Positive
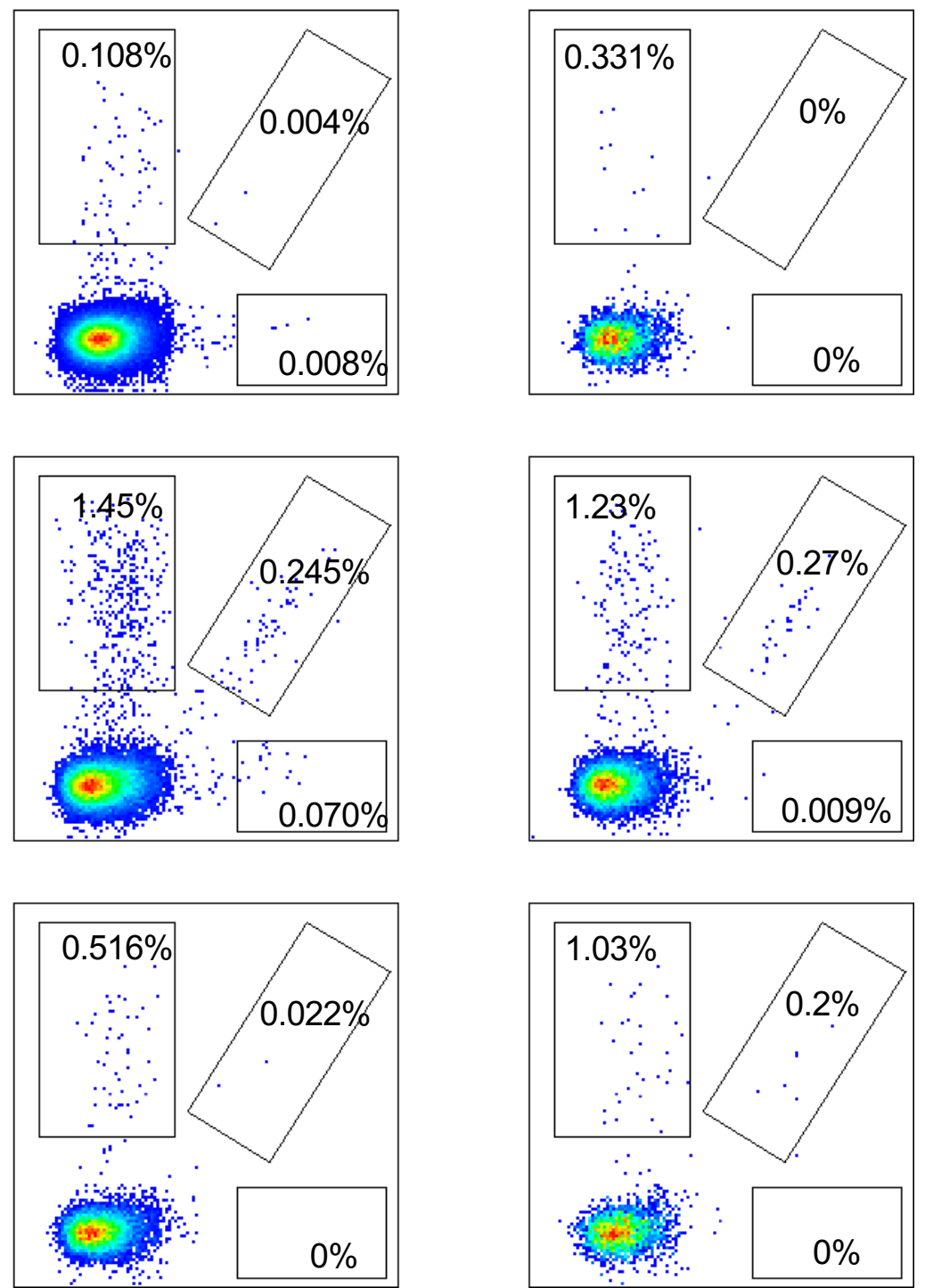

Figure S4. Representative staining of S- and RBD-specific IgD-IgG I $^{+}$cells

3 uninfected subjects (left panels) and 6 subjects after recovery from SARS-CoV-2 infection (middle and right panels). $\mathrm{CD}^{+}{ }^{+} \mathrm{IgD}^{-} \mathrm{IgG}^{+} \mathrm{B}$ cells cells were identified using gating strategy shown in Figure S5. Binding to SARS-CoV-2 spike (S) and/or SARS-CoV-2 RBD probes was assessed. 

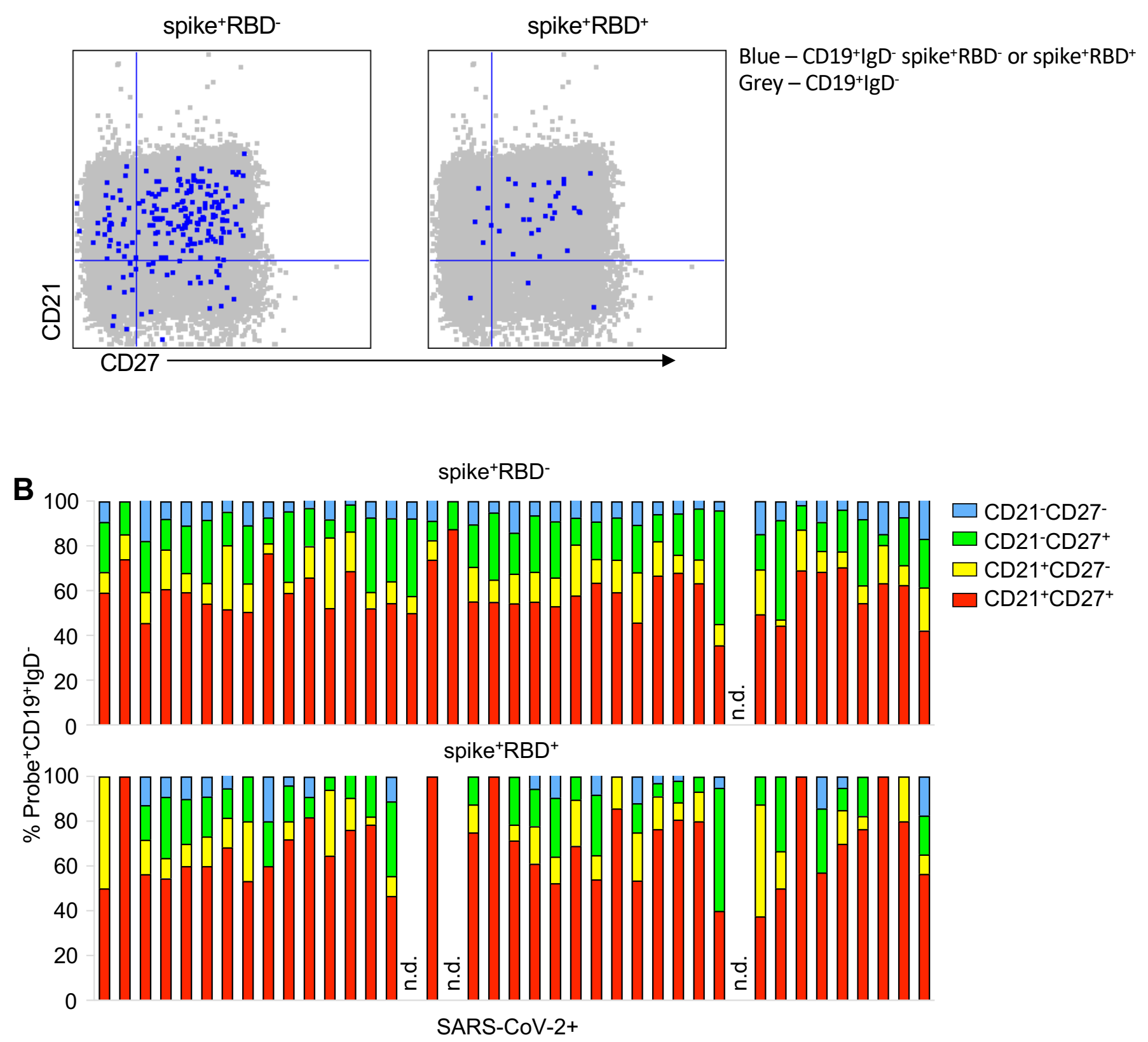

Figure S5. Memory B cell phenotypes in subjects after SARS-CoV-2 infection

(A) Representative memory B cell phenotypes identified by CD21 and CD27 co-stain of probe ${ }^{+} \mathrm{CD} 19^{+} \mathrm{IgD}-$ cells (blue) overlaid on $\mathrm{CD}^{-1} 9^{+} \mathrm{IgD}{ }^{-}$cells (grey) and (B) the corresponding frequencies of the four populations in subjects previously infected with SARS-CoV-2 (Resting memory $-\mathrm{CD} 21^{+} \mathrm{CD} 27^{+}$; activated memory - CD $21^{-} \mathrm{CD} 27^{+}$; naïve $/ \mathrm{CD} 27^{\text {lo }}$ memory - CD21 ${ }^{+} \mathrm{CD} 27^{-}$; atypical B cells - CD21-CD27-); n.d - not detected due to absent probe ${ }^{+}$ cells. 


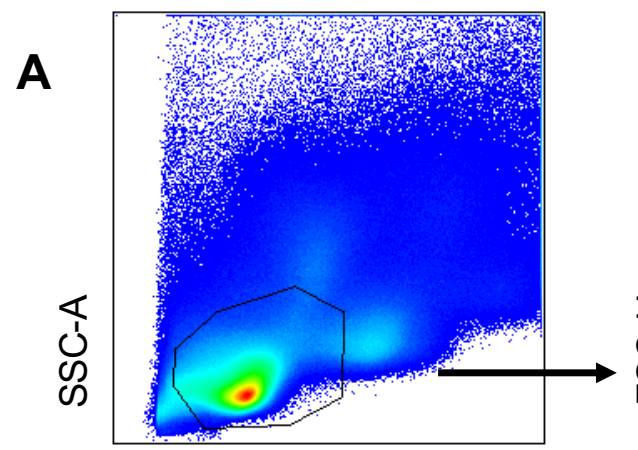

FSC-A

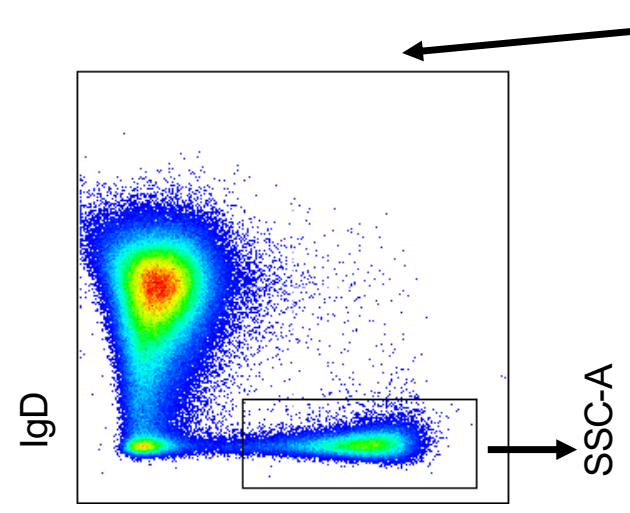

$\lg G$

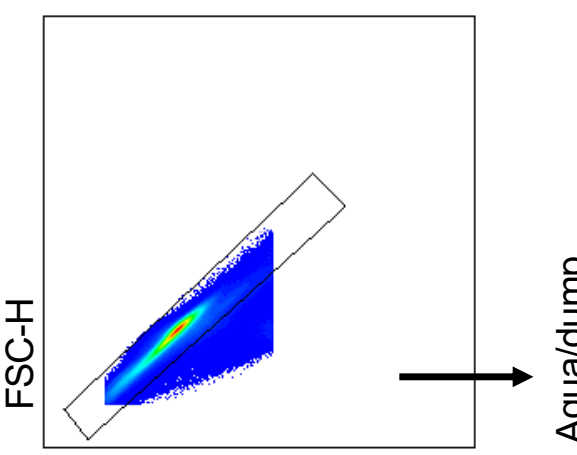

FSC-A

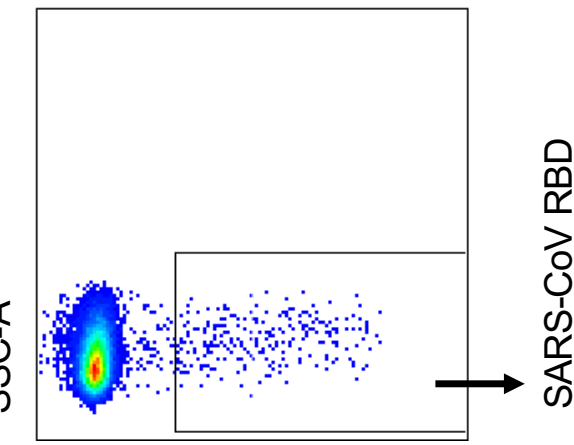

SARS-CoV-2 spike

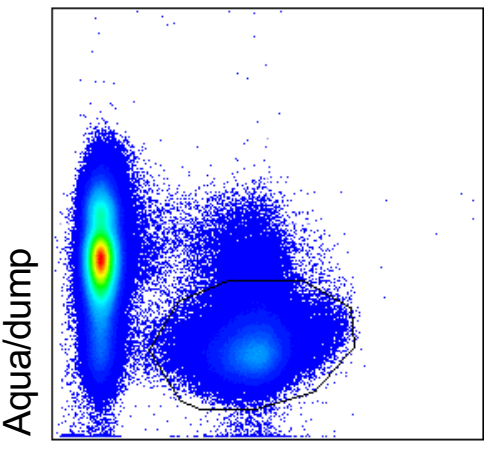

CD19

B

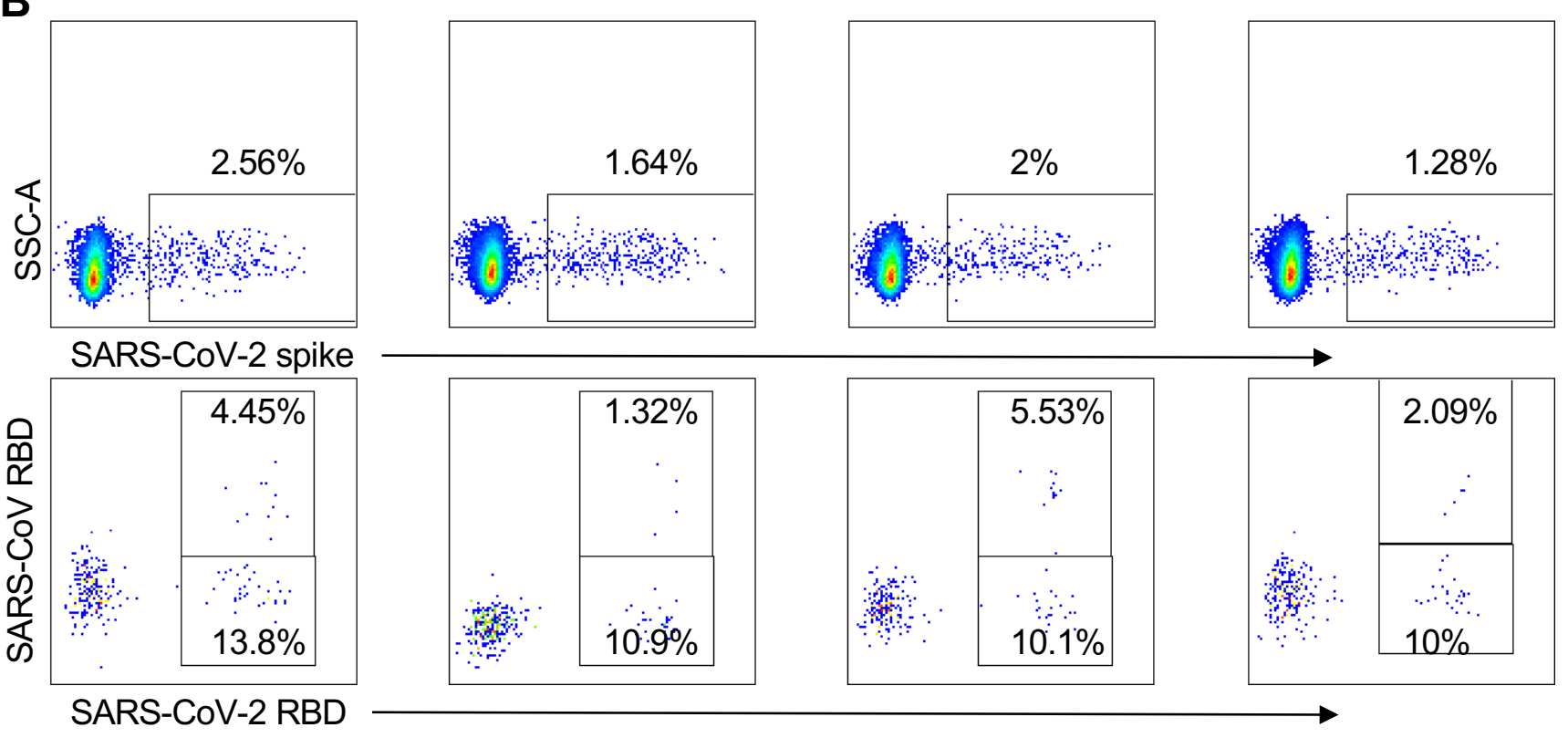

Figure S6. Gating strategy for resolving spike ${ }^{+} \mathrm{CD}^{+}{ }^{+}{ }^{+}{ }^{-} \operatorname{IgG}^{+}$B cells specific for SARS-CoV-2 and SARS-CoV RBD

(A) Lymphocytes were identified by FSC-A vs SSC-A gating, followed by doublet exclusion (FSC-A vs FSC-H), and gating on live $\mathrm{CD} 19^{+} \mathrm{B}$ cells. IgD-IgG ${ }^{+} \mathrm{B}$ cells were gated and assessed for binding to SARS-CoV-2 spike. Cross-reactive specificities versus those unique to SARS-CoV-2 were discriminated by co-staining with SARS-CoV-2 and SARS-CoV RBD probes. (B) Representative staining shown for 4 subjects with prior SARS-CoV-2 infection. 


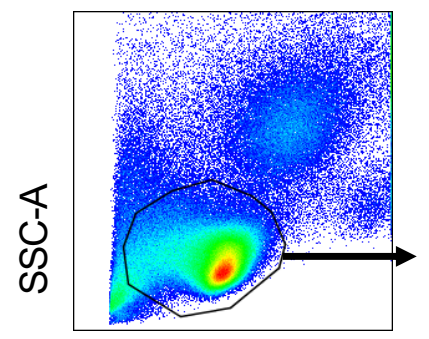

FSC-A

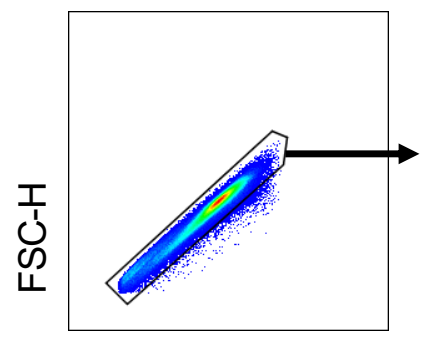

FSC-A

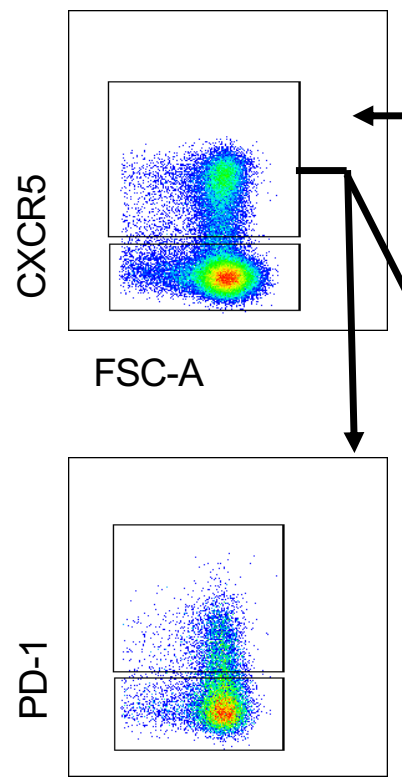

FSC-A
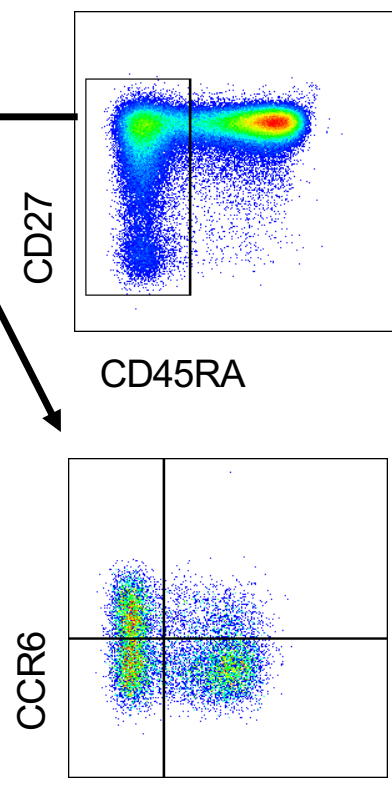

CXCR3
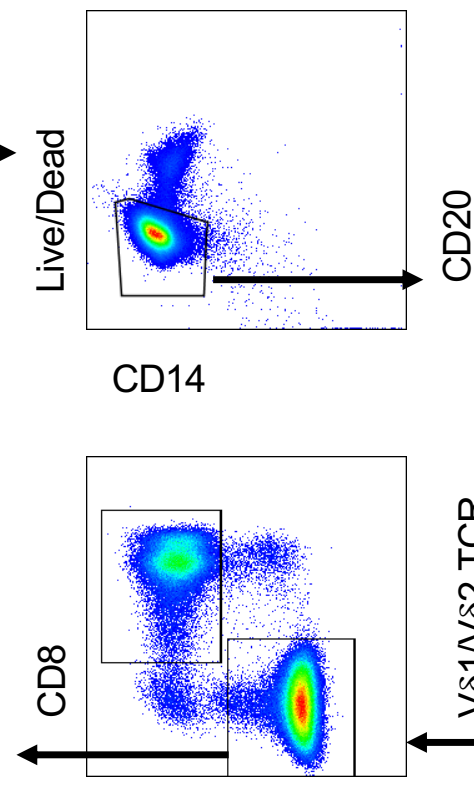

CD4
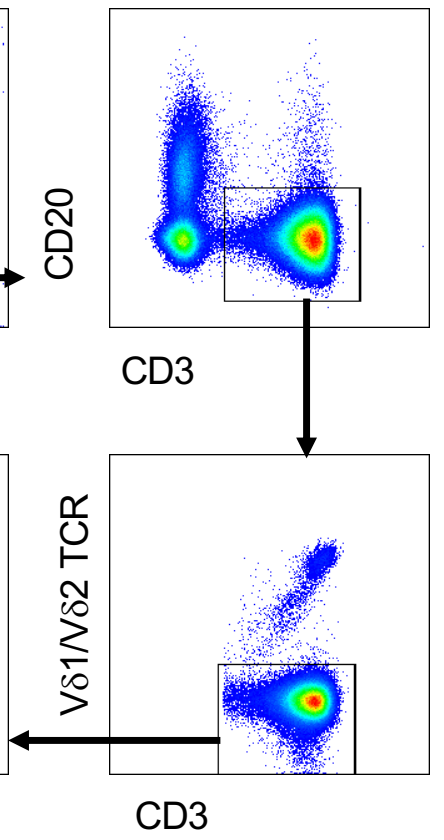

Figure S7. Gating strategy for $\mathrm{cTFH}$ and memory $\mathrm{CD4}^{+} \mathrm{T}$ cell subsets

Lymphocytes were identified by FSC-A vs SSC-A gating, followed by doublet exclusion (FSC-A vs FSC-H gate), and exclusion of dead or CD14 cells. T cells were identified as $\mathrm{CD}^{+} \mathrm{CD} 20^{-}$. Following exclusion of gamma delta $\mathrm{T}$ cells by $\mathrm{V} \delta 1 / \mathrm{V} \delta 2$ TCR staining, $\mathrm{CD}^{+}{ }^{+} \mathrm{CD} 8{ }^{-} \mathrm{T}$ cells were identified. Memory $\mathrm{CD}^{+}{ }^{+} \mathrm{T}$ cells were defined as CD45RA-CXCR5 ${ }^{-}$, while cTfh cells were defined as $\mathrm{CD} 45 \mathrm{RA}^{-} \mathrm{CXCR} 5^{+}$. cTFH cells were further characterized by PD-1 and CCR6/CXCR3 expression. 
A

cTfh Frequency

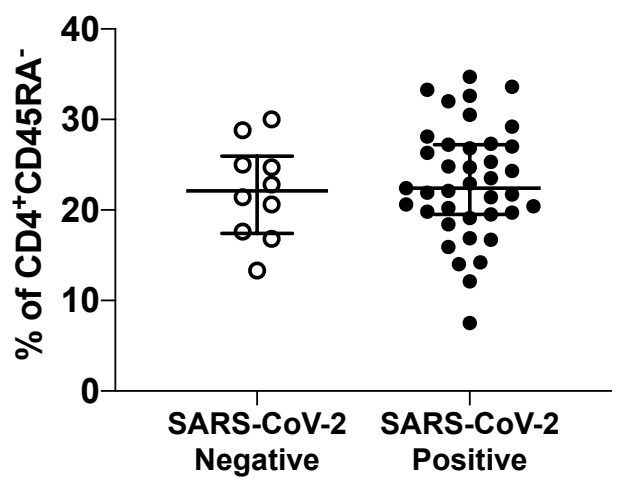

B

Gate: $\mathrm{CD}^{+}{ }^{+} \mathrm{CD} 4^{+} \mathrm{CD} 45 \mathrm{RA}-\mathrm{CXCR} 5^{-}$

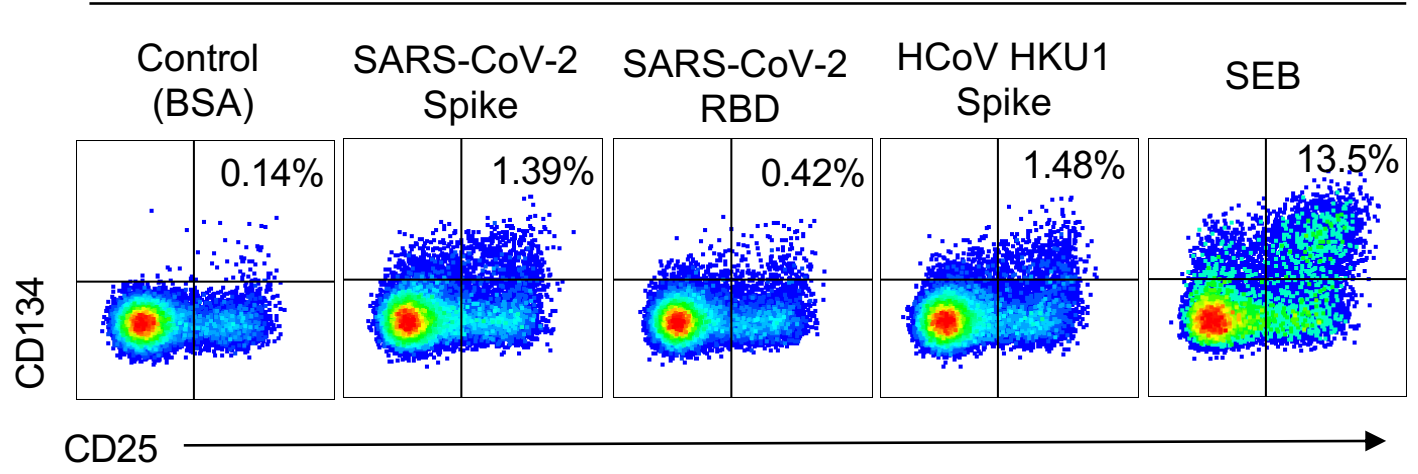

C

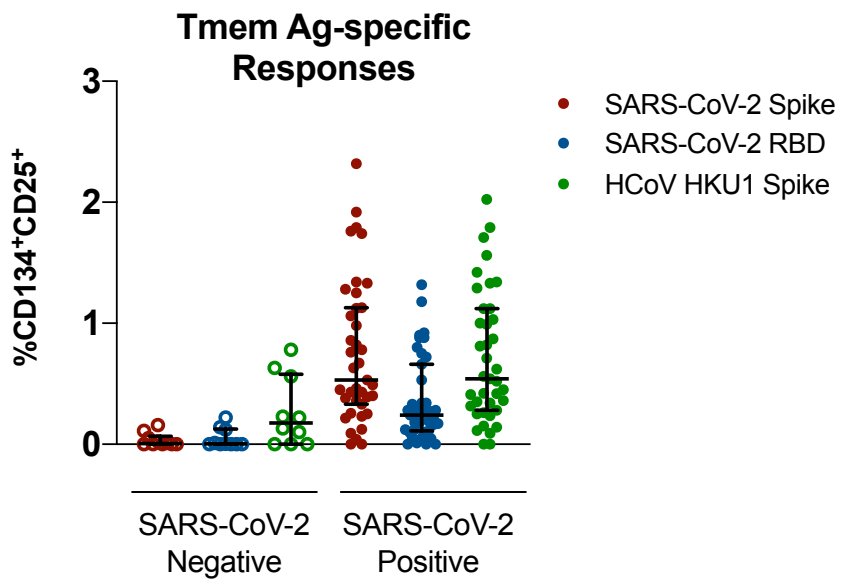

Figure S8. CD4 T cell populations in SARS-CoV-2 positive and negative donors

(A) cTFH frequency (as a proportion of CD4+CD45RA- cells) among SARS-CoV-2 negative $(\mathrm{n}=10)$ and SARS-CoV-2 positive $(\mathrm{n}=39)$ donors. (B) Representative staining of CD134 and CD25 expression following protein or SEB stimulation among CD4 Tmem $\left(\mathrm{CD}^{+}{ }^{+} \mathrm{CD} 45 \mathrm{RA}^{-} \mathrm{CXCR} 5^{-}\right)$cells. (C) Background-subtracted frequencies of SARS-CoV-2 Spike, SARS-CoV-2 RBD or HCoV HKU1-specific CD4 Tmem cells among SARS-CoV-2 negative $(\mathrm{n}=10)$ or SARS-CoV-2 positive $(\mathrm{n}=39)$ donors. 
A

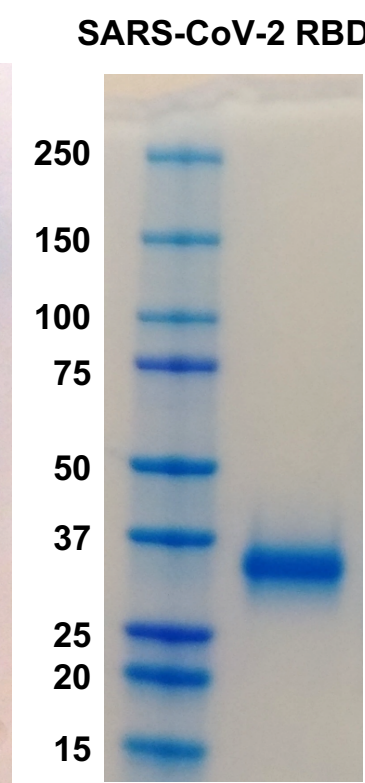

HKU1S

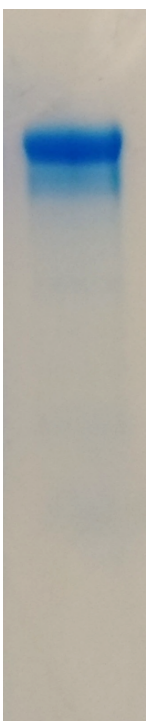

250

150

100

75

50

37

25

20

15

SARS-CoV-2 S

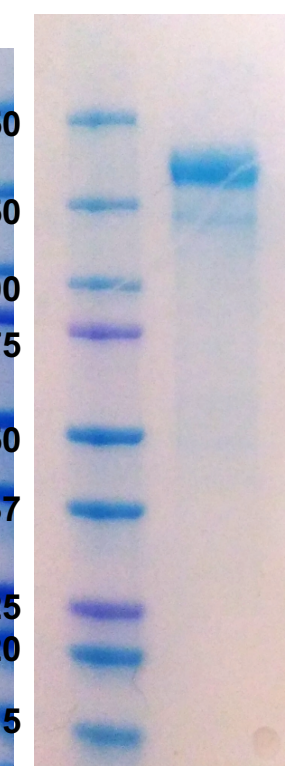

B

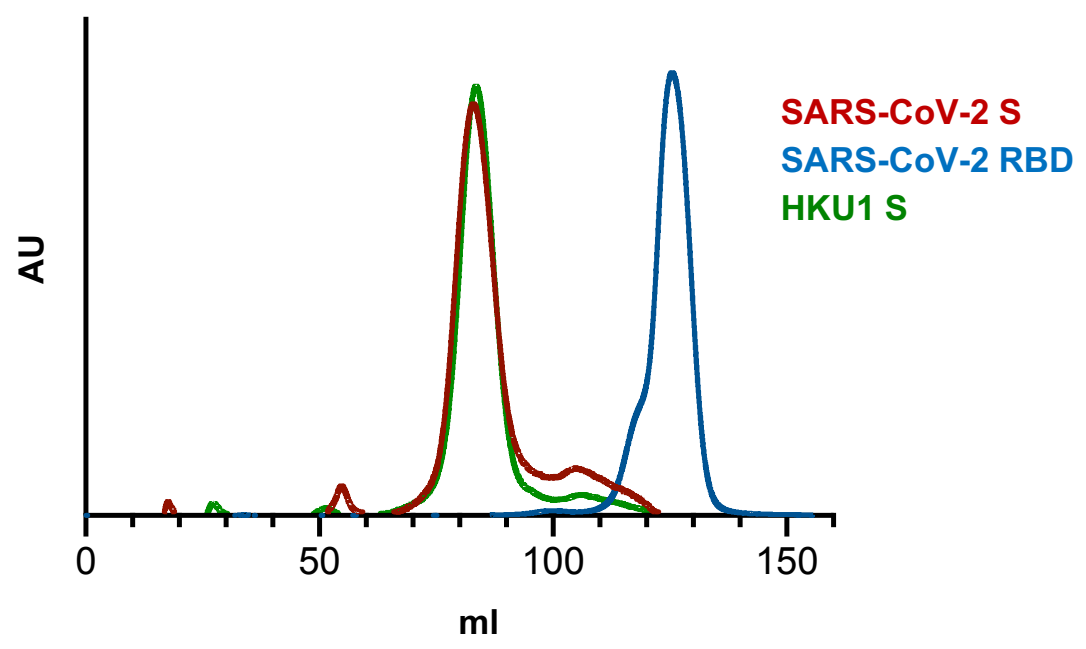

Figure S9. Purification of SARS-CoV-2 S, SARS-CoV-2 RBD and HCoV HKU1 S proteins

S proteins for SARS-CoV-2 and HCoV-HKU1, and the RBD domain of SARS-CoV-2 were expressed in Expi293 cells and purified using Ni-NTA and size exclusion chromatography. (A) SDS-PAGE of purified proteins stained with Coomassie. (B) Gel filtration profiles of recombinant coronaviral proteins run on a Superose 6 16/70 column. 
A Hu Mo

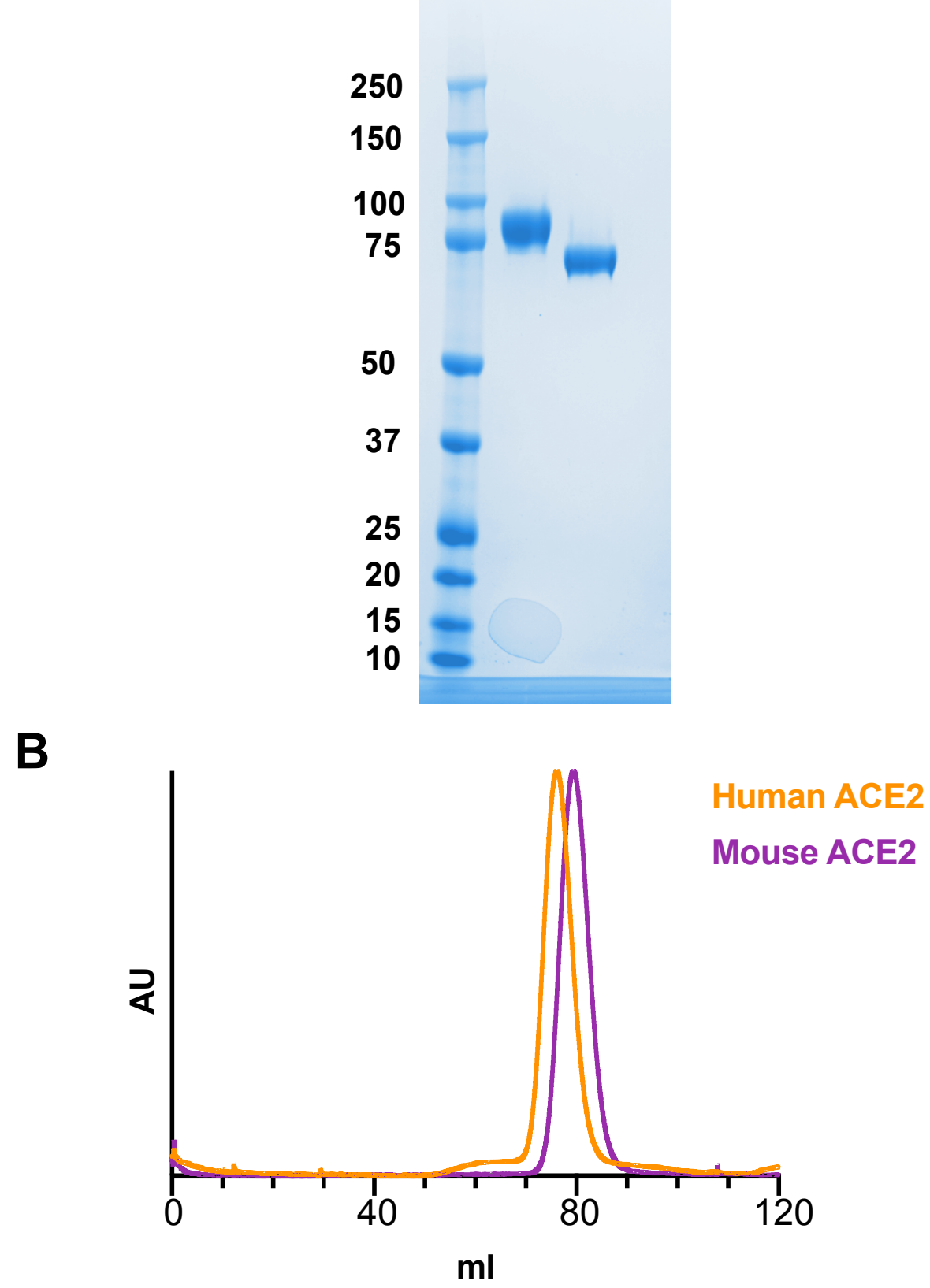

Figure S10. Purification of human and mouse ACE2 proteins. Proteins were expressed in Expi293 cells and purified using Ni-NTA and size exclusion chromatography.

(A) SDS-PAGE of purified proteins stained with Coomassie. (B) Gel filtration profiles of recombinant proteins run on a Hiload 16/60 Superdex 200 Prep Grade column. 
A
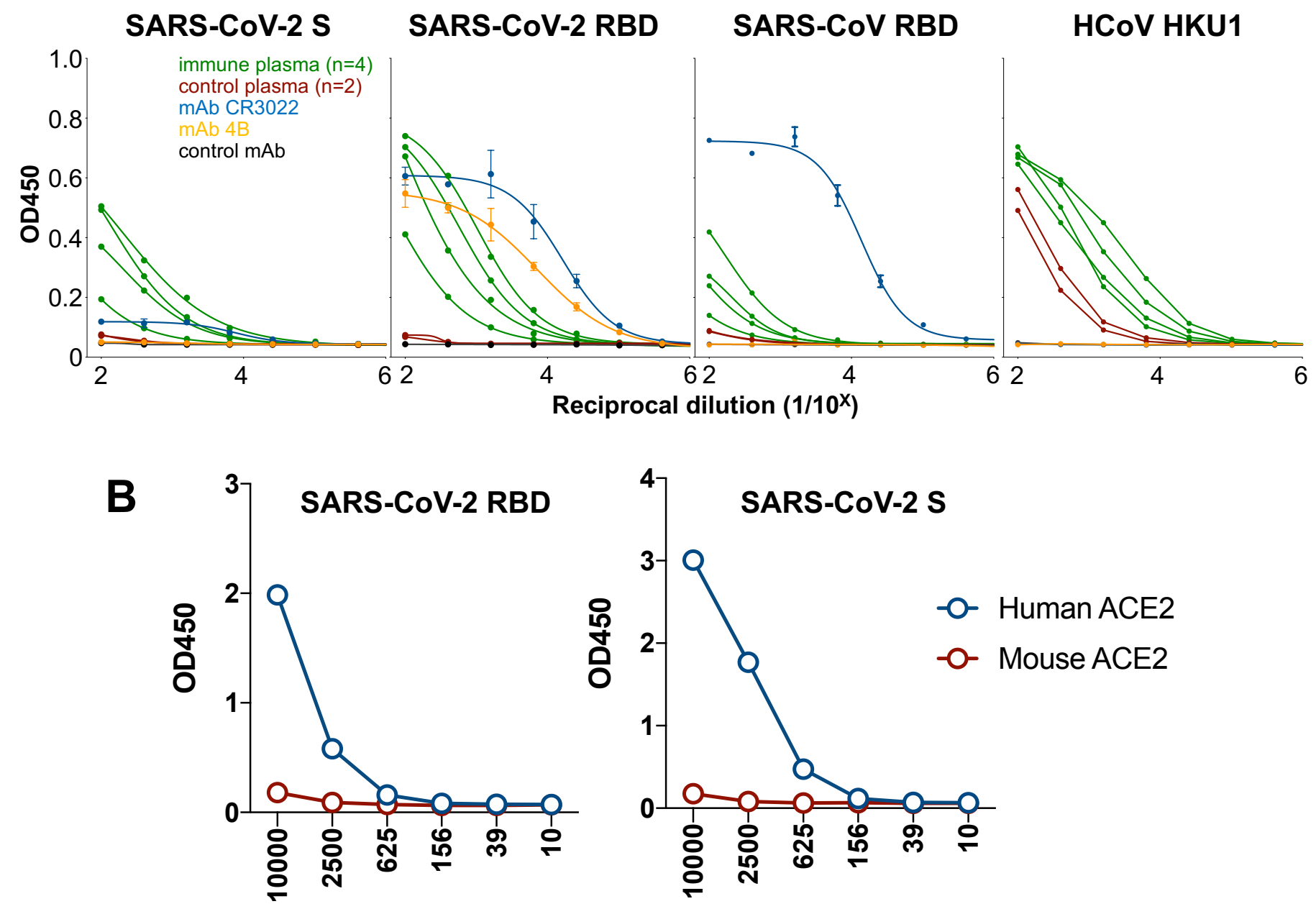

C
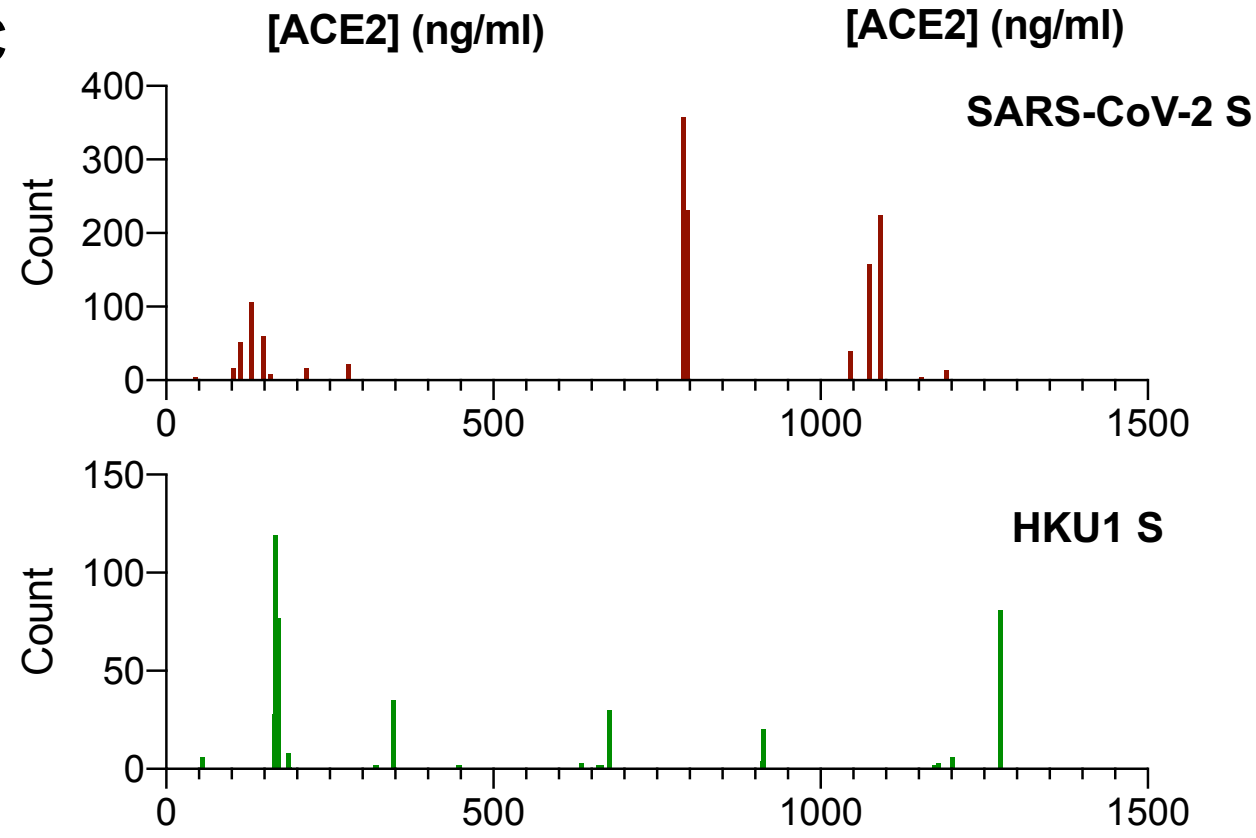

AA position

Figure S11. Antigenicity and glycosylation profile of coronavirus proteins

(A) Plates were coated overnight with $2 \mathrm{ug} / \mathrm{ml}$ of SARS-CoV-2 S, SARS-CoV-2 RBD, SARS-CoV RBD or HCoV-HKU1. Binding to control plasma (red), plasma from recovered SARS-CoV-2 infected individuals (green) or monoclonal antibodies CR3022 (blue), 4B (orange) or control CR8071 (black) was assessed by ELISA. (B) Binding of SARS-CoV-2 S and SARS-CoV-2 RBD to recombinant human but not mouse ACE2 was established by ELISA. (C) Glycan occupancy of SARS-CoV-2 S and HCoV-HKU1 S was assessed using mass spectrometry. 
medRxiv preprint doi: https://doi.org/10.1101/2020.05.17.20104869; this version posted May 21, 2020. The copyright holder for this preprint (which was not certified by peer review) is the author/funder, who has granted medRxiv a license to display the preprint in perpetuity.

Table S1. Characteristics of 41 subjects recovered from COVID-19

\begin{tabular}{|c|c|c|}
\hline Characteristic & Median & IQR \\
\hline Age, median - years & 59 & $(54-65)$ \\
\hline Male sex - no. (\%) & $24(59 \%)$ & \\
\hline Time since symptom onset - days & 36 & $(32-40)$ \\
\hline $\begin{array}{l}\text { Time since +ve nasal swab SAR-CoV-2 PCR* } \\
\text { days }\end{array}$ & 32 & $(28-35)$ \\
\hline $\begin{array}{l}\text { Illness severity** } \\
\text { Mild - no. (\%) }\end{array}$ & $26(63.4 \% *)$ & \\
\hline Moderate-no. (\%) & $10(24.4 \%)$ & \\
\hline Severe - no. (\%) & $5(12.2 \%)$ & \\
\hline
\end{tabular}

* 3 Subjects had a compatible illness and history of exposure but did not have a positive nasal swab

** Illness severity was classified as:

Mild: prominent upper respiratory tract symptoms and not hospitalised.

Moderate: prominent lower respiratory tract symptoms and not hospitalised.

Severe: prominent lower respiratory tract symptoms and requiring hospital care.

Table S2. Age and sex of 27 healthy control subjects without COVID-19 symptoms

\begin{tabular}{|l|l|l|}
\hline Characteristic & Median & IQR \\
\hline Age, median - years & 33 & $(28-36)$ \\
\hline Male sex - no. (\%) & $14(52 \%)$ & \\
\hline
\end{tabular}

